\title{
Caspar Wolf and his personal public commitment to edit Conrad Gessner's unfinished history of plants (Part I: Essay)
}

Holger Funk

\section{Summary}

After completion of his History of animals, Gessner began an equally ambitious History of plants, which, however, he could not complete due to his premature death in consequence of a fatal epidemic. Immediately after Gessner's death, Caspar Wolf (c. 1532-1601), Gessner's former pupil, publicly announced his intention to edit the botanical legacy of his mentor. Wolf's announcement, entitled "Promise" (Pollicitatio), is of prime importance concerning the unfinished plant history and has influenced many researchers' views. However, it has often been forgotten that Wolf had written the announcement also for his own domestic purposes and that caution is therefore required. The present study, complemented by the first full translation of Wolf's text, is intended to reinforce the need for such caution. It is suggested that it was not only Wolf's failings that led to the final failure of the project, but also that Gessner himself may have failed to establish a body of text substantial enough to satisfy his own aspirations.*

Keywords: Caspar Wolf, Conrad Gessner, botanical legacy, History of plants, Historia stirpium, Historia plantarum

\footnotetext{
* I am grateful to Florike Egmond (Rome) and Urs B. Leu (Zurich), who supported my endeavours and in particular to Vivian Nutton (London) and Peter Day (London), who reviewed draft versions.
}

Holger Funk, Kapellenstr. 3a, D-33102 Paderborn (holger.funk@shiba-dog.de). 


\section{The situation}

In early 1566, shortly after Conrad Gessner's death, his pupil Caspar Wolf publicly appealed to Johannes Crato von Krafftheim (1519-1585), Gessner's close friend, with the urgent request to assist him in the publication of the unfinished history of plants of the deceased. Apart from the ostensible motive of serving the scientific community and posterity, what motivated the unknown young Swiss to turn to an internationally recognized celebrity like Crato, and above all with what arguments did he try to lure him to the task?

There are two probable reasons why Wolf decided to turn just to Crato. Firstly, in the middle of the sixteenth century, as a result of growing interest and new discoveries, a history of plants could no longer be coped with by a single scholar. Everyone was dependent on the support of close (neighbours) and distant (correspondents) friends and helpers. Gessner's unfinished history of plants was created in this way. Recent research has increasingly concentrated on these networks of friends and helpers, as they enabled impressive results, especially in the case of Gessner. ${ }^{1}$ The focus is usually on how well such networks operated across national and linguistic boundaries, and one gets the impression that they developed and functioned unproblematically and naturally. That may well have been the case, but there were also downsides of which we know still too little, ${ }^{2}$ e.g. entry or admission into such a circle was not arbitrary, in fact personal idiosyncrasies and animosities played a big role, and above all a newcomer should have an already established reputation. The latter was precisely what Wolf was lacking, and only at the very end of his appeal does he reveal his hidden desire when he begs Crato bluntly "to take me into the circle of your friends" (in tuorum numerum recipias, $\mathrm{P}$ 52r). ${ }^{3}$

Secondly, the scientific situation must be taken into account in order to assess Wolf's motivation. Since the 1530 s, there had been the botanical works of the so-called Fathers of botany, Otto Brunfels, Hieronymus Bock (Tragus) and Leonart Fuchs; but above all since the middle of the century, the numerous writings of P. A. Matthiolus, a notorious opponent of Gessner, dominated

1 See Leu 2016c and Delisle 2008b, in general Dauser 2008; also noteworthy is the study by Wenning 2015 on Joachim Camerarius II, another protagonist of the fate of Gessner's botanical legacy.

2 An exception is the elucidating article by Kempe 2008.

3 Henceforth, the letter "P" plus page number in recto-verso manner refers to Wolf's Pollicitatio of 1566 (B 1 in the bibliography); see also the section Conditions and origin of Wolf's Pollicitatio below. 
the scientific discourse. Most of these works were abundantly illustrated, with plant pictures only occasionally missing entirely.

From today's point of view, it is particularly interesting to know which, besides the illustrations, were the focal points of the early printed herbals. In 1735, at the beginning of his illustrious career, Linnaeus once noted in his Systema naturae: "Classification and nomenclature will be the foundation of our science" (Divisio \& Denominatio fundamentum nostrae Scientiae erit) ${ }^{4}$ Following identification of a plant, naming and ordering (classifying) are fundamental and inseparable, and conditional on each other. By giving a plant a first and a last name, it is automatically assigned a place in an implicit ordering framework, a system; and even if a new name is assigned due to new insights, the plant usually retains its original identity within the system. ${ }^{5}$ The quest to identify and classify plants (at least to order them in some way) belongs to the core tasks of botany, even before the time of Linnaeus. All this can be found in Gessner's botanical legacy in addition to outstandingly good drawings of plants, ${ }^{6}$ a plethora of subtle annotations and observations (by the Englishman Thomas Penny, ${ }^{7}$ next to Gessner's in particular) concerning identification and, albeit less elaborated, classification. ${ }^{8}$ Gessner thereby substantially contributed to overcoming the chaos of plant names and synonyms and the modest approaches of classification prevailing in his day. ${ }^{9}$

In summary, Caspar Wolf had good, mainly personal reasons, but also strong scientific arguments for promoting the publication of Gessner's botanical legacy with the help of such a well-respected and influential personality as Crato von Krafftheim.

\section{Caspar Wolf: life and work}

Our knowledge of the biography of Caspar Wolf (Wolff, Wolph, Wolphius) and his publications is seriously lacking; there is no comprehensive study, and

4 Linnaeus 1735, Observations in Regna III Naturae 10 (no pagination).

5 Thus, for instance, Erica vulgaris (common heather, ling) later became Calluna vulgaris, but the plant still belongs to the Ericaceae family.

6 Which in turn circulated in the Gessnerian network - see as an example the various images of the Terebinth plant in the appendix to my translation (Figure 1 and 2).

7 The present author is preparing the transcription and translation of all Penny's annotations to more than 450 different plants in Gessner's botanical legacy.

8 Which can be inspected in the eight volumes provided by Zoller, Steinmann and Schmid 1972-1980. In volume 8 Zoller emphasizes "Gessner's great systematic talent" (1980, 7).

9 On the last topic, see the astute analyses of Selosse 2012a and 2012b; additionally Arber 1986, 163-184; Ogilvie 2006, 7-8, 215-229; Elliot 2015; Funk 2014. 
even recent overviews ${ }^{10}$ are incomplete, full of errors and contradictory. ${ }^{11}$ Solid information is very rarely to be found; much is left to guesswork or is completely unknown. It is therefore fitting to read and interpret the few reliable historical testimonies carefully, rather than simply copying the work of previous researchers assuming this to be accurate.

It is certain that Wolf was born in Zurich and that his father joined the Reformation. Wolf's father fell (like Conrad Gessner's father) on 11 October 1531 in the Battle of Kappel in Switzerland between the Protestant and the Roman Catholic cantons. However, the year of birth is unclear: some sources indicate 1525, others 1531; his biographer Rudolf Wolf, ${ }^{12}$ a descendant of the Wolfs, who relied on the family register ("Stammbuch"), ${ }^{13}$ gives only 23 March 1532 as his date of birth, that is, Wolf was born after the death of his father and grew up as a semi-orphan. Wolf had several siblings, including an elder brother Johannes (a well-known theologian), who looked after his education. The precise date of Caspar Wolf's death is unknown, but it is thought to be 1601 in Zurich.

Wolf first studied liberal arts (artes liberales), a prerequisite for the study of 'higher' sciences such as medicine, presumably at Basel. Afterwards he studied medicine in Paris, and as a student in Montpellier was tutored and patronized by Gessner from afar. ${ }^{14} \mathrm{He}$ earned his doctorate in 1557 in Orléans. ${ }^{15}$ After graduation, Wolf returned to his hometown of Zurich, where he successfully practiced as a doctor. He also worked as town physician and, after the death of his mentor Gessner in 1565, became his successor as Professor of philosophy. This combined the teaching of Aristotelian physics or natural sciences with ethics at the Collegium Carolinum (also called the "Hohe Schule"), the theological academy that was founded by Ulrich Zwingli and located at the Grossmünster church. ${ }^{16}$ Among his other activities, from 1577 onwards Wolf held a professorship in Greek.

Wolf published a variety of writings, but besides his "Promise" to Crato von Krafftheim, which is to be considered separately, they include only a

10 Brüning 2004, 55; Kettler 2008, 647-649; Jaumann 2011.

11 There is not even an approximately complete bibliography of Wolf's works available. My overview is a first step in this direction; see the Bibliography section at the end.

12 Wolf, R. 1858, 43-56.

13 That is to say, Rudolf Wolf is not a coincidental namesake, as was claimed (Kettler 2008, 649), but an author and descendant of the Wolf family, who possessed valuable documents in family ownership.

14 Wolf, R. 1858, 45-46; Delisle 2008a, 125-126.

15 And not in Montpellier, as was speculated (Kettler 2008, 648; Hirsch 1888, 312). Wolf, R. 1858,47 points to Wolf's diploma he had on hand.

16 See Goeing 2016. 
single independent work entitled Polychymia (1567 A), ${ }^{17}$ and even that only under the pseudonym Diodorus Euchyon. ${ }^{18}$ It is a book on alchemy and distillation techniques, an important topic at this time..$^{19}$ One researcher (Milt 1953) assumed that Wolf only edited this work, but makes no assumptions about the real author. ${ }^{20}$ As Milt (1953) furthermore can testify, Wolf was influenced as a student by some known Paracelsians.

Apart from this singular book of 1567 , Wolf appears mainly as editor, occasionally also as translator from the Greek. ${ }^{21}$ For example, for years he published calendars of prognostic-astrological content (1563-1593 C) as well as other mostly medical works. The writings Wolf edited in connection with Gessner are of particular interest (block B of my bibliography). Yet there must also be mentioned an inglorious piece of misconduct (to put it politely), which Wolf committed at the beginning of his career, and in which he implicitly involved his esteemed patron and mentor Gessner. As the Gessner biographer Hans $\mathrm{H}$. Wellisch has revealed, ${ }^{22}$ Wolf in 1565 edited under the title Viaticum novum the lectures of a supposedly unknown physician, which he pretended to have discovered. Shortly before his death Gessner himself had written a preface to this work in good faith. Antoine Valet (Valetius), a French physician and translator, maintained that these notes came from the French physician Jacques Houllier (Hollerius, $d$. 1562) and accused Wolf of plagiarism. On the occasion of the publication of another of Gessner's writings, Wolf repudiated this accusation (Euonymus, 1569b B), but in 1578, in a new edition of Viaticum novum, he had to admit ruefully that Valet was right.

Finally, in the 1590s Wolf began a remarkable collection of medical manuscripts and letters to and from Gessner, which were never published, but which Wolf used for his purposes. This collection is preserved under the title Thesaurus medicinae practicae (1596 C) in the Zurich Zentralbibliothek, but has not been systematically evaluated, although its existence has long been known. ${ }^{23}$

17 The capital letter behind the year here and in the following refers to blocks $\mathrm{A}$ to $\mathrm{C}$, into which I have divided my bibliography.

18 Not "Euchyontis" or "Euchyontus", as Brüning 2004, 55 writes. "Euchyon" means "the well-pouring one". The whole pseudonym could be translated, adequately to a book on distillation, by "the man with the divine gift of well-pouring".

19 See Debus 1978.

20 Milt 1953, 194-195.

21 Regarding his Dioscorides translation of 1581, see Riddle 1980, 116-117.

22 Wellisch 1984, 97, 103.

23 Delisle 2008a: 216, 348-354, 379; Blair 2010: 213-224; Wellisch 1984: 114; Baumann 1953: 123. 
An accommodating biographer once called Wolf one of the "more outstanding" physicians of the sixteenth century. ${ }^{24}$ However, it is more likely that but for his close personal connection to Conrad Gessner and his work, Wolf would be completely forgotten by now. In any case, one should separate the question of Wolf's abilities as a physician and scholar from the question of his services to Gessner.

\section{Wolf's relationship to Gessner}

Wolf's "Promise" (Pollicitatio) to Crato von Krafftheim to present the unfinished history of plants of the recently deceased Gessner to the scholarly world, was a publicly pronounced action which ultimately harmed Wolf more than that it was useful to him. Since he did not keep his promise, he has always been condemned as the one who was unable to cope with the task. Before I go into Wolf's work, however, one of the most persistently stated stereotypes has to be discussed, namely the relationship between Gessner and Wolf.

At the beginning of his Pollicitatio, Wolf describes how Gessner, shortly before his death, took him into his confidence and urged him to complete and publish the unfinished history of plants in his name [P 46v]:

At first he showed me not only in its respective place the many and different materials for the composition of his History of plants (Historia stirpium) that he had scattered in his "Museum" here and there, as it is usually the case with an abundance of activities, but time and again he suggested (commendat) to me in both word and deed that I should take care of it. And although Gessner had already indicated to me earlier, when he used my services to arrange this matter and to read through some books of this kind, how by what plan such a great work could be carried out, now that he thought he had to leave this to me, he showed me everything more completely and in better way. [...] He asked me (a me petiit), what he ought to have demanded in his own right, that I undauntedly should undertake to execute this difficult, yet useful and longed-for work under his name, if the Lord were to call him from this life.

These words would appear to underscore that any initiative came from Gessner, and above all, that Gessner had a special relationship to Wolf. Wolf's words have prompted biographers to call Wolf a "friend and official colleague" ("Freund und Amtskollegen"), ${ }^{25}$ even a "favourite pupil" ("Lieblingsschüler") of Gessner. ${ }^{26}$ The term "colleague" is certainly justified, because Wolf too was a town physician in Zurich and Gessner also calls

24 Hirsch 1888, 312; not one of the "most important" physicians, as Brüning 2004, 55 wrongly quotes Hirsch.

25 Hanhart 1824, 280, 292.

26 Wolf, R. 1858, 45. 
him a "collega". But what did the courtesy title "favourite pupil" mean, which has been repeated by many biographers? The expression first and foremost aims at Wolf being a student of Gessner at the Carolinum. We are quite well informed about these students, ${ }^{27}$ and we know some students by name like Josias Simmler, Johannes Fabricius Montanus (Schmid) or Georg Keller (Cellarius), who later also belonged to Gessner's closest friends. In particular, Gessner's brother-in-law Keller, like Wolf an assistant to Gessner at the Carolinum, and later likewise municipal physician and together with Wolf successor in the chair of Physica, had been equally intensively promoted by Gessner in his years of studies. Gessner, thus, had several privileged pupils, but whether Wolf was actually his "favourite pupil", who was closer to him than any others, we do not really know. Gessner does not address Wolf in this manner, but speaks of Wolf as his "fellow citizen and colleague, who by unusual necessity is bound fast to me, indeed an excellent doctor". ${ }^{28}$ Of what kind this "unusual necessity" (necessitudine non vulgari) was that "fettered" (devinctum) him to Wolf, remains open to speculation. ${ }^{29}$ It certainly was not, as Wolf insinuates, his special familiarity with the botanical material of Gessner that distinguished him above all others. Johannes (Jean) Bauhin the Younger was equally well-informed (and more competent) about Gessner's botanical project; the same applies to the Englishman Thomas Penny. Gessner and Penny, however, had met personally only shortly before his death in $1565 .{ }^{30}$

The second stereotype concerns Wolf's status as the administrator of Gessner's botanical material. Frequently one can read that Wolf "inherited" this material from Gessner or that he was Gessner's "literary executor". ${ }^{31}$ The first to state that Gessner had left everything to Wolf by "testament" (testamento) and that Wolf "would be the heir, so to speak" (haeredem quasi fore),

27 Leu 2016a, 119-126.

28 Concivem meum et collegam necessitudine non vulgari mihi devinctum, medicum sane excellentem, Gessner in the foreword to the reader in Wolf $1565 \mathrm{~B} 3$.

29 It seems not far-fetched to assume that Gessner, who to his regret remained childless, felt a special emotional closeness to the fatherless Wolf. In a letter to Adolph Occo of 5 May 1564 (Gessner 1777, 63r) Gessner writes: "For the fact that one has well-behaved children is the most important part of human happiness, which I am lacking so far and without doubt will be lacking further on, since I am already a man of old age". According to Simmler 1566, 2, Wolf and Georg Keller "took the place of sons" for Gessner (filiorum loco habuerit). On Keller, see Rüetschi 2016.

30 On Penny (c. 1530-1589), see Raven 1947, 153-171, on Johannes Bauhin (1541-1612), see Fuchs-Eckert 1977; Penny as well as Bauhin inspected and extensively annotated Gessner's collection of plant images, see note 39. Penny later made many more annotations to Gessner's botanical legacy than Wolf (418 versus 154 on 814 illustrated folios). They were praised by a botanical expert as "extremely accurate" (Milt 1936, 289).

31 E.g., Delisle 2008a: 348, Wellisch 1984, 101. 
was Wolf's co-author Josias Simmler. ${ }^{32}$ Against such a description, however, it should be noted that Wolf does not appear in Gessner's testament of September 1564, and that there can be no talk of an inheritance. Wolf himself says $(1581,2)$ that he had "purchased" (comparavi) $)^{33}$ everything and thus he later could sell parts to Joachim Camerarius II and possibly to Felix Platter and Thomas Penny. ${ }^{34}$ As Wolf continues to say, Gessner "transferred" (translata) the material to him on the basis of an "agreement" (ex pacto, $\mathrm{P} 47 \mathrm{r}$ ). To speak of Gessner's "legacy" (described as such for brevity and convenience in this essay) and of "inheritance" is permissible only in a metaphorical, not in the strictly legal sense. This is not simply a linguistic quibble, since an inheritance implies more than a sale for payment the expression of a personal appreciation. On the other side, an inheritance is subject to testate succession (patrilineal, matrilineal inheritance, or absence of offspring). ${ }^{35}$ When Wolf sold the botanical material to Joachim Camerarius the Younger (Camerarius II) around 1580, the whole bequest was passed down within the Camerarius family for generations, and finally this problem of a missing male succession actually occurred when Joachim Camerarius III, the son and heir of Joachim Camerarius II, did not leave a male descendant at his death in 1642. As a consequence, Gessner's botanical legacy was passed to the daughter of Camerarius III, and thus for the first time into another family, since the daughter had already married into the Nützel family in Nuremberg. ${ }^{36}$ This marked the beginning of the fragmentation of Gessner's botanical material. In the end, we have to leave open what motivated Gessner to sell the botanical material to Wolf and not to inherit it, but it remains a somewhat strange feeling.

In this context, another point sheds light on Gessner's relation to Wolf more specifically. Wolf says that he had to pay "a certain price" (certo precio, P 46v) for Gessner's whole materials, which, as Wolf observed elsewhere, ${ }^{37}$ was "not small" (non exiguis sumptibus). The well-informed Simmler (1566, $19 \mathrm{v}$ ) called it a "legitimate price" (iusto precio). Again, it is to be noted that on the part of Gessner the sale was less a favour or a special price for a friend, as one might have expected, but more of a business-like transaction. ${ }^{38}$

In conclusion, we cannot say exactly why Gessner in the face of death entrusted his botanical material to Caspar Wolf. Wolf generally speaks with

32 Simmler 1566, 15 r.

33 Wolf 1581, 2.

34 Leu et al. 2008, 6-7.

35 See Rein 1858, 772-852.

36 Schmiedel $1751 \mathrm{~b}$, XLVIII.

37 Wolf 1581, 2.

38 Only the generally uncritical Hanhart 1824, 280 much later called it "an extremely cheap price". 
respect to Gessner of "a certain love and benevolence towards me" (amore et benevolentia erga me quadam, P 46v). However, these feelings did not go so far that Gessner gave or even bequeathed to Wolf everything without further ado, and apparently there were also profound personal motives in play. It is safe to say that Wolf was not predestined and therefore favoured by Gessner because of his special botanical abilities. There were better experts in Gessner's vicinity, for example, Johannes Bauhin, who himself was working on a Historia stirpium and communicated with Gessner about this intensively. ${ }^{39}$ Thus, when Wolf remarked to Crato von Krafftheim that he was "put into such embarrassment" 40 because he (Wolf) was "not particularly suited by virtue of genius or scholarship, or by practical experience" ${ }^{" 41}$ for this task and, finally, that Gessner "had bestowed on me more than I could actually cope with" ${ }^{42}$ then all this can also be taken literally, not just as affected modesty. The common understanding that Gessner bequeathed or handed down his botanical remains to Wolf because he was his favourite pupil explains nothing. Obviously a number of motives played a role that we can no longer disentangle; but perhaps it was simply a spontaneous decision in a perilous situation.

\section{Conditions and origin of Wolf's Pollicitatio}

In 1564, an epidemic of pleuritis reached Zurich, which Gessner survived unscathed and actively combatted as a town doctor. The epidemic ebbed at the end of the year, but reappeared again even more violently in the summer of 1565. At the beginning of December Gessner himself was affected, and after a few days he fell prey to the epidemic on the $13^{\text {th }}$ of December.

Close friends and confidants, among them Gessner's former pupils Josias Simmler, Georg Keller and Caspar Wolf, stood by Gessner's side until the end. From this narrow circle, the idea was born to create a literary monument

39 See Bauhin's De plantis a divis sanctisve nomen habentibus (1591) and in the same work for instance Gessner's letter to Bauhin from 29 August 1565, (p. 156): "I hear you are writing a Historia stirpium too. If that is the case, I wish you good luck in this matter, and that you do not hide anything from me, who, of all things, can best bear rivals. It is far from me, believe me, to dissuade you from your proposition, rather I will support you as far as I can. You have seen many things here [in Zurich in my documents], and you are able to achieve many things that I am not able to do and you are still young." Gessner and Bauhin also made together some botanical excursions.

40 In eas angustias sum redactus, $\mathrm{P} 46 \mathrm{v}$.

41 Cum etenim neque ingenio aut doctrina, neque rerum usu egregie sim instructus; P 51v. See also the editors' comments on Wolf's poor botanical knowledge in the Faksimileausgabe (Zoller et al. vol. 3, 1974, 81 and vol. 4, 1976, 95).

42 Plus mihi quam revera praestare possim, tribuerit, $\mathrm{P} 46 \mathrm{v}$. 
in honour of the deceased and to make his life and work better known to the public. Josias Simmler (Simler, Simlerus, 1530-1576), a pastor in Zurich and distinguished theologian and historian, who had also excelled as an astronomer, acted as the editor of this testimonial. In 1574, Simmler made another outstanding contribution to Gessner by editing a considerably extended version of his Bibliotheca universalis. ${ }^{43}$ To the book of honour Simmler contributed a detailed Vita Conradi Gesneri and added Gessner's own overview of his publications of 1562 (De libris a se editis epistola). In addition, a series of poems by different people on the occasion of Gessner's death in Latin and Greek were printed in the volume. The other contributor besides Simmler was Caspar Wolf with his "Promise". ${ }_{44}$

The book of Simmler and Wolf appeared as early as 1566, the contributions being written in an extremely short time. Simmler dated his text as 22 March, Wolf his Pollicitatio as 14 March 1566, that is, only three months after Gessner's death, in which, as Wolf says, he was dealing with the very extensive and varied material (materiam amplissima et varia, $\mathrm{P} 49 \mathrm{v}$ ) he had taken over from Gessner. And equally noteworthy is the addressee of his work, Johannes Crato von Krafftheim, one of the closest friends of Gessner, personal physician and consultant at the imperial court in Vienna and a widely recognized personality. ${ }^{45}$ The recipient of Wolf's petition could hardly have been more prestigious.

Crato and Gessner had never met each other personally, ${ }^{46}$ just like Wolf and Crato. When Wolf was given the coat of arms privilege by the Emperor, the imperial diplomat Johann Ulrich Zasy (Zasius) stayed in Zurich, ${ }^{47}$ and Wolf presumably took the opportunity to make contact with Crato via Zasy (Wolf 1858, 48). The biographer Wolf gives 1566 as the year of the encounter and in this context names Emperor Ferdinand I, who however had already died in 1564; more probably he meant Ferdinand's son and successor Maximilian II - otherwise the meeting of Wolf and Zasy must be backdated to 1564 or even earlier. But not only is the exact date unclear, one would like to know why at all Wolf was distinguished this way. A coat of arms was a

43 Titled Bibliotheca instituta 1574 and 1583. For more on Simmler, see Wyss 1892; Coolidge 1904, CXLVII-CLXV; Taplin 2011.

44 There exists a shortened German translation of Simmler's Vita Conradi Gesneri (Anonymous 1711), the rest of the book remained untranslated.

45 On Crato von Krafftheim, see Gunnoe and Shackelford 2009; Gillet 1860-1861; Fossel 1909, 24-45.

46 Simmler 1566, 18.

47 Zasius was also involved in the negotiations for Gessner's coat of arms privilege, see Gessner's letter to Crato von Krafftheim of 8 January 1564 (EM 1577, 15v). Henceforth, "EM 1577" refers to Epistolarum medicinalium Conradi Gesneri philosophi et medici Tigurini libri III, that is, to Wolf's edition of 1577. 
special recognition for outstanding merits, a precursor to nobilitation, as we know, for example, from the coat of arms granted to Gessner in $1564 .{ }^{48}$ Wolf, on the other hand, was only 30 years old between 1564 and 1566, had not yet appeared as an author, and was at most known as a physician in Zurich. One cannot avoid the impression that Wolf understood just how to use the favour of the hour and to advance himself. A reaction from Crato to Wolf's spectacular advance in public life is unknown to me.

\section{Wolf's outline of Gessner's Historia stirpium}

\section{The images}

To underline the urgency and desirability of an edition of Gessner's legacy, Wolf presents in detail the content and structure of the planned history of plants. These explications are at the centre of his work, framed by urgent requests to Crato von Krafftheim to support this task. Interestingly, Wolf begins his sketch with an analysis of the visual material, not the textual remains. For Wolf there were good reasons to proceed in this way; one of them, of course, was the relevance of pictures to the whole project. ${ }^{49}$

In the last few years substantial research has been provided that elucidates the importance and provenance of the images in Gessner's zoological and botanical writings. ${ }^{50}$ These efforts gained a further impetus when, thanks to fortunate circumstances, most recently new images and sources pertaining to Gessner's work were rediscovered in Amsterdam and in Tartu, Estonia. ${ }^{51}$

As Wolf emphasizes, Gessner had been interested in plants and their presentation from his youth onwards (ab ipsa adolescentia, P 48r). ${ }^{52}$ Gessner benefited from this enduring interest while working on his new plant book.

48 Leu 2016a, 245-249.

49 As to other reasons, see section What happened to Gessner's texts? below.

50 Kusukawa 2011 and 2012, 138-161; Egmond and Kusukawa 2016. Gessner's woodcut images, which were later redrawn and engraved in Erlangen, are described in Schnalke 1995, 338-341.

51 Regarding the Amsterdam discovery, see Egmond 2013 and 2016; regarding Tartu, see Rand 2014 and 2015; Leu 2016a, 294-296 and 2016b; Nyfeller 2016.

52 See Gessner (1542 C, $\alpha$ ij): "I think you remember that my great-uncle Johannes Frick, a man as virtuous as dignified, was very well versed in botany. He took me away from my father as a child, fed me all the time in his house, sometimes led me out into the open, and taught me to cultivate his richly planted garden. There he spent with me the recreation hours and told me the names of the plants so often that I could bring him at his command any plant he called from the garden or from the field." Johannes Frick was the uncle of Gessner's wife, cf. Leu 2016a, 14-17. 
As well as collecting woodcuts from the herbals of others and pictures from Kentmann's Codex, he also collected and procured his own plant material, drew pictures himself, and supervised the transfer of the drawings into woodcuts and engravings. For example, he writes to Achilles Pirmin Gasser on 26 June 1563 (EM 1577, 27v):53

I also decorate my plant book with more zeal than ever. For the individual illustrations (drawings, engravings) I bring live plants from the solid land, meadows, fields, footpaths, vineyards, gardens, hills, mountains, forests, rivers, streams, marshes, lakes, banks and where else plants thrive.

In a letter to Adolph Occo (EM 1577, 64v), Gessner emphasizes: "I am very anxious to draw seeds and flowers in the most accurate way." But Gessner not only paid attention to the fact that the plants were painted in a lifelike way, but placed particular value on a correct representation of the proportions, as we learn from Wolf's co-author Simmler $(1566,15 r)$ :

Before Gessner became ill, many plant pictures had been made into woodcuts, he himself often being present with the painter when the copies were made; and he was careful, first of all, to ensure that the true proportions were preserved in all the paintings, that the painter did not show off his art but imitated nature and approached it as closely as possible, and that not the fibres of the leaves, the veins of the flowers which the painter himself preferred, but those which nature had formed would be most accurately represented.

We must therefore acknowledge that Wolf recognized the importance of plant pictures for Gessner's work and rightly emphasized them. In order to highlight Gessner's achievements Wolf understated the overall situation and simultaneously suggested an impressively high number of Gessner's plant pictures, which from then onwards is found repeated in most literature (P 48r):

Since Gessner had over a period of almost twenty years (as from his youth on, he was led to this study by a natural impetus) collected a great number of plant pictures with great judgment, diligence and extreme zeal, supported by the efforts, nighttime work and gifts of many friends from Italy, Germany and France, through which the collection had grown to 1,500 different pictures.

Estimates of the number of illustrations in Gessner's botanical legacy vary greatly. However, a reliable figure is important to ascertain in order to calculate the extent of Gessner's planned plant history, if it ever had been published during his lifetime. Nearly all authors quote Wolf's specification of 1,500 drawings, including Schmiedel ${ }^{54}$ or, most recently, Leu. ${ }^{55}$ This high number was contested by Heinrich Zoller, thereby subtly correcting his

53 As to "EM", cf. note 47.

54 Schmiedel 1751b, XLIII; a little later, Schmiedel 1751b, LIII speaks of 1,600 pictures. 55 Leu 2016a, 296. 
former Wolfian specification of 1,500 images. ${ }^{56}$ Zoller now identified ca. 1,100 plants (from family or genus level, but with the vast majority identified as to the species and a minor number as to subspecies or variety); most recently, Nyffeler similarly mentions only 1,000 different plants. ${ }^{57}$ To add clarity, I have checked the figures anew. A meticulous, computer-aided evaluation of the descriptions of all 829 illustrated and annotated folios (from $2 \mathrm{v}$ to $493 \mathrm{r}$, without blank pages) in Zoller's Gesamtausgabe of 1987-1991 revealed that Gessner's botanical legacy contained in fact 1,541 pictures and drawings of plants or plant parts. Wolf's specification is therefore reasonable and acceptable, regardless of possible or - not infrequently - impossible identifications.

In addition to stating the high number of pictures, Wolf, in order to make an impression, also outlines the general situation of plant presentations somewhat worse than it really was (P 48v):

And while, regarding the proportion and size of the pictures, so far it has not been sufficiently taken into account by those who were concerned with the representation of plants that on the one hand the buyer (of the book) would not be financially burdened, and on the other side the one who is studying the pictures would not obtain dissimilar, scalemismatched images (if the largest as well as the smallest plants have the same size without difference), the most circumspect and wise Gessner provided ... (different formats for the larger and smaller plants).

This alleged disproportionality of the images may be true of the incunabula herbals from the end of the fifteenth century, but certainly not for the time of Gessner, when the illustrated works of Brunfels, Bock, Fuchs and others had already appeared. ${ }^{58}$ Gessner himself writes to Crato von Krafftheim on

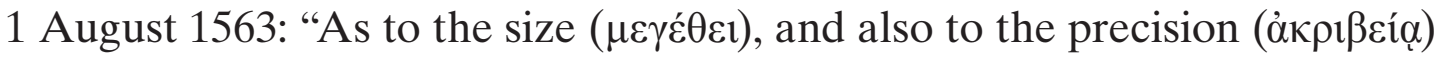
of images true to nature, there is already a noble competition among men, and I feel as if I would accuse all others of the common charge of negligence and insignificance." ${ }^{59}$

\section{General set-up and arrangement}

Gessner thought carefully about the structure, extent and arrangement of the botanical material as well as the general orientation of the new work. He had to decide whether his history of plants should serve as a lexicon or an encyclopaedia. A 'lexicon' was a reference book for targeted reading

56 Zoller 1991 and 1965.

57 Nyffeler 2016. Treviranus 1855, 20 and Baumann et al. 2001, 23, 85-86 argued that originally 1,500 drawings existed, but only ca. 1,100 have survived; however, I found no evidence for this statement.

58 See Anderson 1983 and 1984.

59 Wolf $(1577,13 r)$, cf. Helmich 1938, 35. The sentence is written in Greek. 
as opposed to an ancient and medieval 'encyclopaedia', which was intended to explain the whole world (Pliny) or to enable a biblical exegesis of nature (Thomas of Cantimpré, Bartholomeus Anglicus, Vincent of Beauvais) and could be read through. ${ }^{60}$ In contrast to an encyclopaedia, which was systematically designed, a lexicon was alphabetically structured. Traditionally, such an alphabetical order was the predominant way of structuring. ${ }^{61}$ Following approved models (Galen, Fuchs) as well as Gessner's own previous approaches such as the Historia animalium and some earlier attempts, ${ }^{62}$ he decided to adapt the plant history to be an alphabetical lexicon (P 49v):

Gessner finally decided to organize and explain each topic in alphabetical order, which he had used before in his Historia animalium, following the example of Galen and the highly learned Fuchs. Gessner was partly drawn to this plan because he had previously arranged numerous sheets in this way and so could use the work of other scribes more easily, ${ }^{63}$ but partly also because the future book should be constructed in the manner of a lexicon, so that not only physicians, but also other users easily could find what they were looking for.

More difficult than the question of the general intention and the basic order was the question of the extent and the internal structure of the individual plant descriptions. This question had bothered Gessner considerably, as Wolf reports $[\mathrm{P} 49 \mathrm{v}-50 \mathrm{r}]$ :

In addition, Gessner has also dealt for a time with the question of whether it would be better or more expedient to summarize everything in a single volume, or to divide it into different volumes because of the differences in matter. And since he would have written extensively, comprehensively and carefully about everything that can be said about plants, for which reason the book was intended to be partly a grammatical one (liber Grammaticus) in which names and etymologies were explained from the Greek, Latin, Arabic, Hebrew etc., but also in part a natural philosophy or natural history (liber Physicus seu Historicus), which would include descriptions of the individual plants, their genera and species, the time at which they bloom, germinate, produce seeds or fruits, and much more of this kind. However, in part it was also a medical book that chiefly would have been concerned with the powers and effects of the plants, as they are used for food or medicine - (because of this broad range,) he again pondered whether it would not be fairly appropriate to make a subdivision into three independent books. [...] But after he had decided to combine everything together, thereby conflating the material in one and the same work if he had remained alive, he pointed out to me that I, too, if he should depart this life, should obey the procedure and method which he had observed earlier in the history of animals.

60 See Alpers 1990; Friedrich 1995, 18-24. As was noted by Bäumer 1991b, 13, the term 'encyclopaedia' itself was coined not before the end of the fifteenth century.

61 Habermann 2001, 155-164; Miethaner-Vent 1986. The first botanist explicitly to reject an alphabetical sequence was Hieronymus Bock (Hoppe 1969, 35-43; Habermann 2001, 162-163; Bäumer 1991a, 202-206;. Green 1909, 239). Gessner has written a long preface to Bock's De stirpium commentariorum libri tres (1552), but has not followed Bock in this respect - on the contrary, in the prefaces of the individual volumes of his Historia animalium, he always refers to the alphabetical arrangement (cf. Friedrich 1995, 57-58).

62 See Müller 2001, 483-487.

63 This, most probably, refers to the so-called loci (or loci communes) method discussed below. 
In Gessner's Historia animalium each entry was subdivided into eight sections simply headed $\mathrm{A}$ to $\mathrm{H}$, with approximately the following content. ${ }^{64}$ Thus we have: A: names and synonyms ${ }^{65} \mathrm{~B}$ : geographical distribution; C: way of life; D: psychic life and physiology; E: benefits for humans; F: foodstuff from animals; G: drugs from animals; H: philological questions (Gessner's special passion) such as etymologies, epithets, metaphors, parables or fables; ${ }^{66}$ this last section again is subdivided into the sections $\mathrm{a}-\mathrm{h}$. Such structuring was widespread in Gessner's time, and was already applied in similar form in the herbals of Brunfels (1532) and Fuchs (1542).

Gessner, thus, was scarcely innovative, in fact he did not invent anything new, but participated in the tradition of the herbals of his time. However, compared to his history of animals Gessner set new accents, primarily necessitated by the difference between plants and animals. ${ }^{67}$ What this difference was is better understood from the section "G", which is about vegetable drugs. Wolf has characterized this section as follows [P 51r]:

The seventh chapter, with the letter "G", will contain the remedies and faculties of the simple medicines, composed of books of ancient and more recent authors, of many manuscripts, of own experiments, and those of friends; it will also include the temperaments and secondary, tertiary and quaternary faculties. In this chapter will be mentioned many marvellous things and mysteries of nature and everything will be given exhaustively in a very extensive and ample form.

Wolf's extremely brief description of the "faculties" may have been sufficient for an absolute expert like Crato von Krafftheim, but it was rather incomprehensible for most other non-experts. Especially for a modern reader it is essential to give a more precise explanation.

According to the ancient (Hippocratic/Galenic) theory of the four humours each substance (animal, vegetable, mineral) has the primary



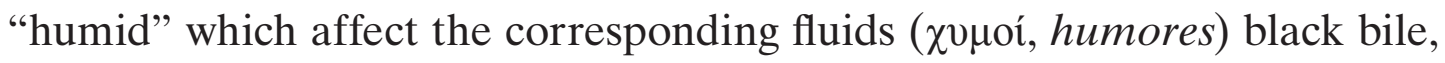
yellow bile, phlegm and blood in the human body. The mixing ratio or combination (complexio) of these properties determines the specific "tem-

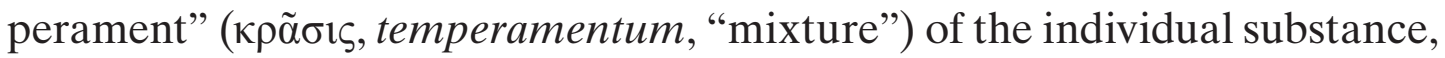

64 See Gessner 1551, $\gamma 1 \mathrm{v}-\gamma 3 \mathrm{r}$ ); Leu 2016a, 203 and Bäumer 1991b, 46 provide concise summaries.

65 Names were of major importance, see for example Gessner's letter to Johannes Fabricius of 2 August 1564 (EM 1577, 93v): "When it happens with the fish of the ocean that we do not know the names of the ancients because they are not described by them, but only those of the Mediterranean Sea on whose shores the Greeks and Romans lived, so it is not surprising if the same happens by what grows on land."

66 See Friedrich 1995, 70-71; Müller 2016.

67 It is obvious that terms such as Genera, Tempus (season), Locus (locality) or Cultus (cultivation) mean something different in plants than in animals. 
its balance (or imbalance, "dyscrasia") in the human body indicates the state of health (or disease). When describing the effects of medicinal or dietary substances, and, to a much lesser extent, the state of the ill patient, writers further divided these four qualities in ascending order into four degrees ( $\tau \dot{\alpha} \xi \varepsilon 1 \varsigma$, gradus, ordines) of intensity, from 1 (mild) to 4 (powerful), thus allowing a correlation between illness and therapy. Besides these so-called primary qualities, secondary qualities such as tastes (e.g. sweetness, bitterness) and medicinal effects (e.g. astringent, cleansing) were considered (Harig 1974; Nutton 1993).

In the Latin and German herbals of Fuchs (1542 and 1543), these qualities and degrees are dealt with in the sections "Temperamentum" ("natur und complexion") and "Vires" ("krafft und würckung") of each plant drug. Fuchs had also dedicated a special publication (1541) to this subject, ${ }^{68}$ exactly like Gessner with Historia plantarum et vires (1541), his very first botanical work. Similarly, the herbals of Bock (1546 and 1552) have a section "Vires ac temperamentum" ("krafft und würckung"). In the case of Camerarius (1586a), who later took over the botanical legacy from Wolf, the corresponding sections are headed "Qualitates" and "Vires". In 1543 Johannes Dantz published a huge cross-reference of all known Galenic and Dioscoridean herbs and their compositions and gradual effects, and in 1569 P. A. Mattioli published an equally extensive list. It was the predominant theory and practice in sixteenth-century medical botany ${ }^{69}$ but such specifications played only a minor role in zoological works such as Gessner's Historia animalium. For his Historia stirpium, by contrast, Gessner had planned a separate section "Temperamenta et facultates", as can be concluded from a larger fragment on the plant "Abrotonum" that is reproduced by Schmiedel. ${ }^{70}$ Gessner's entry "Abrotonum" refers to present-day Artemisia abrotanum, in German vernacular commonly called Eberraute or Stabwurz, in English southernwood ("Sotheron vvood", as Gessner spells it). It is a species of today's genus Artemisia (mugwort), itself a name of controversially etymological origin, comprising several species. ${ }^{71}$ In short, there was a great need of clarification as this problematic plant was widely spread and used, and

68 See Harig 1966.

69 Except for the Paracelsians, who rejected humoralism, see Debus 1978, 27.

70 Schmiedel 1751a, 46-54.

71 In the ancient sources there was a great uncertainty about the status of "Artemisia" and "abrotonum/abrotanum", see Genaust 1983, 31, 60; Sauerhoff 2001, 86; Schmidt 1905. By Pliny (Naturalis historia 25.36.73) and some Greek authors two different names were

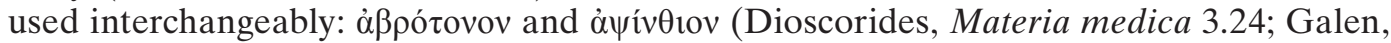
De alimentorum facultatibus 731). Johannes Bauhin 1593 has devoted a separate study in order to clarify the complex matter of Abrotonum-Absinthium-Artemisia. 
therefore Gessner's entry is a useful case for an evaluation of the different approaches by Gessner and Fuchs.

Prior to Gessner, it was mainly Fuchs who had attempted to provide new insights. His entries "Abrotonum" or "Stabwurtz/Staubwurtz" from 1542 and 1543 respectively have two images of a "male" and a "female" specimen [Figure 3] and expound the plant in seven brief sections headed Nomina, Genera, Forma, Locus, Tempus, Temperamentum, and Vires. Gessner's Abrotonum description is basically identically structured to that by Fuchs, but has three more sections (in brackets corresponding to sections in Gessner's Historia animalium):

Nomina (A), Genera et species, Tempus (C), Locus (B), Cultus (E), Sympathia et antipathia (D), Alimenta (F), Temperamenta et facultates (G), Succedanea (missing), and Philologica (H).

New compared to Fuchs are the sections Sympathia et antipathia ${ }^{72}$ and Philologica, the content of all other sections is only distributed differently by Gessner than to that of Fuchs. Completely novel, with parallels neither in the Historia animalium nor in Fuchs, is Gessner's section Succedanea ("substitutes"). This is remarkable insofar as here for the practising physician or apothecary alternatives are specified in case a particular plant is not available or is too expensive - an acute problem since antiquity ${ }^{73}$ to which Gessner had already devoted one of his first publications (Succiduorum medicaminum tabula, also known as Actuarius, 1540). All in all, the most obvious difference between the Abrotonum entries of the two herbalists is not the general content but the extent: while Fuchs's contribution covers only one and a half pages, Gessner's article comprises more than eight closely printed pages - the rest being lost. In addition, five pictures were reserved for Gessner's article, while Fuchs had only two. And especially the section on temperaments and faculties is much shorter (together one page) in Fuchs ${ }^{74}$ than in Gessner (more than four pages).

This brief analysis makes it clear that Gessner indeed, as indicated by Wolf, was structurally closely aligned with the arrangement in Historia

72 This refers to what in terms of modern botany is called allelopathy (that is, chemical interactions between plants) and what was known since Greek-Latin antiquity as "sympathy"

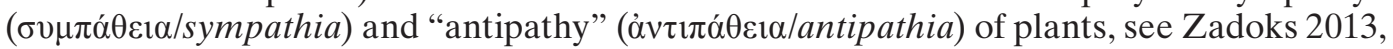
138-140; as to the Paracelsian concept of these terms, see Debus 1978, 27. Under these keywords, however, Gessner obviously also understood the ecological sensitivities of a plant. In the Historia animalium, Gessner superficially understood by the two terms things such as the strife for food between animals living together (for example, between horses and camels).

73 See Touwaide 2001; Riddle 1992.

74 Fuchs 1542, 8-9. 
animalium; it further shows that Gessner was inspired by a proven concept of an established botanist such as Fuchs. The main difference from Fuchs is to be seen in the far greater scope of his descriptions, both with respect to the variety of topics and to the number of pages. If Gessner's project had been completed in the extensive manner of the Abrotonum fragment, it would have considerably exceeded the 900 pages of Fuchs' herbal, given the fact that Gessner solely in the first two volumes of his botanical legacy had amassed (as indicated above) pictorial material of more than 1,500 different plants. ${ }^{75}$ Thus Wolf was not wrong in alluding to the impending cost escalation and the prospect that such a work might be unsaleable. It seems natural to surmise in the sheer mass of material another reason for the final failure of the enterprise. ${ }^{76}$

\section{What happened to Gessner's texts?}

As Wolf remarked, Gessner had hoped (speraverat) to complete the planned history of plants within two years (intra hoc biennium, P 47v). Such confidence presupposes that much work had already been done. As Wolf continues, Gessner had indeed done such preparatory work (P 47v):

Gessner has consulted more than 200 other (books) according to their suitability in composing this natural history, of which he has collected and examined most himself, a certain part, however, I (had gathered) at his direction. Anything that was useful to this subject was fully described, or at least briefly noted, in order to retrieve it later.

This collection of more or less detailed evidence was obviously based on the widespread loci method, which was used to arrange alphabetically or systematically significant textual fragments (keywords, names, terms, sentences, examples, etc.) from the literature. It was a very effective way to keep track of everything, to retrieve it comfortably and to elaborate it. In the first place, however, it was - and that is crucial - only an assemblage of excerpts collected in a slip box and not an elaborate, coherent text, even though the testimonies

75 Originally, Gessner's plan looked different. In an early letter (Gessner 1584 s.p., letter to Kentmann of 16 March 1555) he stated that he intends to write his new plant history, in contrast to his animal books, "briefly and concisely" (breviter arguteque). See also the sceptical judgement by Carolus Clusius: "I cannot refrain from holding the opinion that Gessner's labours will probably result in a huge volume if it is permitted to judge from his other works. But works of this kind seem to be more sumptuous and laborious than ingenious." (letter to Crato von Krafftheim of 5 December 1569, Treviranus 1830, 49).

76 In a letter in Latin to Theodor Zwinger in Basel of 9 May 1569 Wolf reports: "I already have the woodcuts (formas) of 700 plant drawings, and the letter A, which will contain 200 woodcuts, is already finished." A facsimile of the letter is available at http://www.e-manuscripta. $\mathrm{ch} / \mathrm{bau} / \mathrm{content} /$ pageview/8897 (accessed March 2018). Also to be considered is the fact that a competent helper like Thomas Penny stayed in Zurich only for a short time and then returned to England - see Funk 2018. 
were gathered for this purpose. Gessner's Bibliotheca universalis (1545) and Pandectae (1548) as well as his Historia animalium, for example, have been regarded as a successful transformation of such a loose collection of fragments into a continuous long text. ${ }^{77}$ Yet no such collection itself has survived from Gessner; we only know that he preferred this method.

We also know that Gessner had either collected or made himself a large number of plant drawings that were littered with an abundance of notes (the Gessner volumes in Erlangen and Tartu can be found online). But we do not have an insight into whether and to what extent these notes had already been transferred into a structured context. If this had been the case, botanical descriptions should have been included in Wolf's acquired material. However, such descriptions are never mentioned, either by Gessner or by Wolf. ${ }^{78}$ This begs the question of the creation of comprehensive manuscripts, not just scattered notes on slips of papers - a question that to my knowledge has not been addressed by anyone, since attention has focused mainly on the plant images themselves. What then can be concluded about the existence of such elaborate manuscripts from the most reliable Gessnerian sources, his letters? To anticipate the answer: alarmingly little.

Gessner had tackled his endeavours on the Historia stirpium in 1560, that is, after the provisional ${ }^{79}$ completion of Historia animalium and the illustrated corollary books titled Icones. ${ }^{80}$ From this date onwards, notes concerning a planned new plant history can be found in Gessner's correspondences - for example in a letter to Didymus Obrecht from 1560 (EM 1577, 115r) or to Achilles Pirmin Gasser of 7 June 1561 (EM 1577, 23r): "With the plant history I progress, but at a turtle's pace." In his Horti Germaniae (1561: 237) Gessner for the first time publicly announced his intention to edit a Historia stirpium.

The next letter of 5 November 1562 (Bauhin 1591, 111), this time to Johannes Bauhin, lessens the expectations somewhat: "I see that I will hardly be able to tackle editing of the history of plants to be written (stirpium historiae scribendae) before spring." Shortly before, on 12 October 1562, Johannes Fabricius Montanus in Chur, with whom Gessner corresponded extensively about plants, had emphatically exhorted him to advance the plant history (EM 1577, 92r).

77 See Krajewski 2011, 9-17; Friedrich 1995, 61-65; Leu 2007.

78 Wolf mentions only the herbarium, all the sheets (schedas) and the needed books (P 46v), without saying what the contents of the "sheets" were; according to Hanhart 1824, 292, these sheets formed Gessner's loci collection.

79 The fifth and sixth volume on snakes and insects were not yet finished and were published only posthumously in 1578, see Wellisch 1984, 65 .

80 See Delisle 2008a, 52, 91, 122; Leu 2016a, 272. 
But in the spring of 1563 , Gessner reaffirms his resoluteness in a letter again to Achilles Pirmin Gasser of 17 February 1563 (EM 1577, 24r): "I hope I will finally force myself to the plant history."

In the autumn of the same year, Gessner writes in a letter to Johannes Hospinianus of 3 October that he dedicates himself to the history of plants in his short leisure time (EM 1577, 104r), and in a letter to Felix Platter of 17 October 1563 once again underlines the importance of his plant book (EM 1577, 98v): "My occupations, however, concern the benefit of the public, which, I trust, will be promoted by my extensive labours in editing the history of plants."

A short time later, however, Gessner reports a severe setback in a letter to Johannes Crato von Krafftheim of 12 November 1563 (EM 1577, 15r):

My history of plants has not yet begun (nondum est inchoata), as far as the external form of the work is concerned. I am still stuck in the material. For the most part, I collect it from old [sources] and from my own observations. Those things, which besides the ancient more recent authors have added, are very scarce.

At the beginning of 1564 , Gessner reports in a letter to Johannes Kentmann dated 16 February that he had finally withdrawn from the Historia stirpium in order to edit his book on stones and metals (Gessner 1584: s.p.): "I have withdrawn from the whole history of plants. In the meantime, I see myself forced to publish the prematurely born book on stones and metals, which I hope will happen next summer." ${ }^{81}$ In October 1564 Gessner constructed an index of all plant images so far made for the project, that was used and extended by Wolf, but which unfortunately has not survived..$^{82}$

At the end of the year, Gessner writes in a letter to Adolph Occo of 12 December 1564 (EM 1577, 53v) that he cannot say at all when he will complete the plant work and that he will now devote himself to the reading of the relevant literature.

When I hope to conclude my work about the plants, I cannot precisely delineate or promise even to myself, let alone to someone else. So far I have undertaken to read a great deal, which I will then excerpt, so that I can publish the work, as far as I can vouch for it, as completely as possible.

After a year of stagnation in writing, the situation suddenly reversed, and Gessner is now overwhelmed by the resumed work, as he reports in a letter to Johannes Bauhin of 16 March 1565 (Bauhin 1591, 153): "I am almost submerged in my ocean of plants, and buried under a multitude of things." At the same time, however, in a letter to Gasser of 31 March 1565 (EM 1577, 41v),

81 Gessner's miscellany book De rerum fossilium appeared in the summer of 1665 . It was his last work published in his lifetime, see Wellisch 1984, 99-100 and Etter 2016.

82 See Schmiedel 1751b, LIII. 
again stagnation is reported, and it looks as if Gessner somewhat was losing track of his own work: "I have interrupted my history of plants for many months, and it is progressing very slowly, perhaps it will never be finished."

How great Gessner's misery was, ${ }^{83}$ is best illustrated by a letter to Theodor Zwinger in Basel of 8 April 1565, in which he informs Zwinger that he urgently needs aid, preferably a young, reliable student to support him in his work on the plant history (qui mihi scribendi ac describendo navaret operam, EM 1577, 111v-112r). Gessner was successful in his quest because on 9 July 1565 he writes to Johannes Bauhin (Bauhin 1591, 154) that he actually has found the needed assistant: ${ }^{84}$

The descriptions you gave me - for which service I will one day show my gratitude - were already described for me by Adrianus Chortander, whom you know and who is now with me and helps me to organise the rest of the material for my history of plants. ${ }^{85}$

The successful placement of an assistant gives the project a new boost, as is to be read in a letter to Crato von Krafftheim of 5 September 1556 (Simmler $1566,18 \mathrm{v})$ : "I will devote myself again to my ocean of plants, after I have postponed everything else."

At last, in the autumn of 1565 , Gessner has reached the situation he was striving for in spring of 1563 . Thus, on 11 October, two months before his death, he writes to Johannes Bauhin (Bauhin 1591, 158): "At the moment I am completely hidden behind plants, and I ask you, if you have something pertaining to this subject-matter, to communicate it to me in intervals, in order to make me happy."

The next message in a letter to Crato von Krafftheim of 20 October again sounds very optimistic (Simmler 1566, 18v): "I have tackled the history of plants, which has to be put together from 260 [other] books. So far, I do not regret this immense labour, however extreme it may be."

Finally, the last note on this subject, in a letter written in Greek to Adolph Occo of 4 December 1565, Gessner is also very confident (EM 1577, 58r):

I am not surprised that Fuchs has finished his plant book after such a long time. Mine, I believe, will be much better. However, I cannot say when it will be finished. I hope this will happen within a year. ${ }^{86}$

83 Not least because Gessner's printer Froschauer also exerted pressure regarding the costs see the letter to Adolph Occo dated 26 September 1565 (Wolf 1777, 65r).

84 Cf. Delisle 2008a, 82-83.

85 Little is known about this Adrianus Chortander, except that he was a Dutchman who also appears in Gessner's Liber amicorum, see Durling 1965, 137; Gessner refers to Chortander on folio 165v of his botanical legacy, see the Faksimileausgabe (Zoller et al. vol. 5, 1974, 28 and 77).

86 Converted into today's standard typography of ancient Greek, Gessner's text reads: tòv

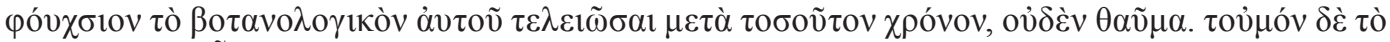

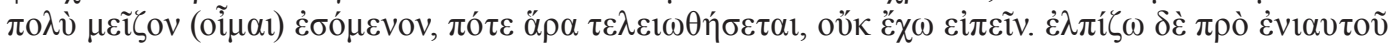

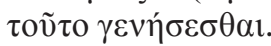


In the face of Gessner's remarks in his letters since 1560, and in view of his constant complaints how physically stressful working had become to him, his confidence at the end of 1565 is difficult to comprehend. In fact, there was little reason for such an optimism. Time and again, Gessner expressed his will to start working, but there was - except for the numerous annotations to the drawings ${ }^{87}$ - no real progress, instead a constant back and forth. Frequently Gessner was impeded or distracted by other projects, ${ }^{88}$ until complete stagnation at the beginning of 1564 . When the work gained momentum in autumn of 1565 with the support of a Adrianus Chortander (Wolf was, as Gessner remarks ${ }^{89}$ busy with other things), it was too late. On 13 December, Gessner fell victim to the epidemic, without having had time to give the work an appropriate form.

The whole story reminds us in a peculiar way of a similar situation in which Gessner had once been. When Leonhart Fuchs in 1556 planned a revision of his Historia stirpium of 1542 and asked Gessner if he could provide him with material and information, Gessner refused him with the following reason (letter to Fuchs of 18 November 1556, EM 1577, $137 \mathrm{v}-138 \mathrm{r}):{ }^{90}$

I have many varied observations, noted down on numerous papers, rather than described in a more convenient form, in such a way that they could only be used by me; and I don't have the time to write them down properly. And I have perhaps more in my head than on paper.

Unless we are entirely mistaken, Gessner ended up in the same situation as in 1556 , when he had a lot in his head for his history of plants, ${ }^{91}$ but had almost nothing in elaborated written form. ${ }^{92}$ Under these conditions Wolf did

87 Only a fraction of Gessner's plant pictures preserved at Erlangen University is deciphered or translated, as was confirmed to me by Martin Steinmann (Binningen, Switzerland), the responsible co-editor of the Gesamtausgabe (1987-1991) and the Faksimileausgabe (1972-1980). Many annotations are now no longer reasonably readable, as we realized when Steinmann and the present author were together trying to decipher some of them.

88 To be mentioned are the fifth volume of Valerius Cordus's Historia stirpium (1563), and especially Gessner's book on stones and metals (1565).

89 Letter to Theodor Zwinger of 8 April 1565: Vuolphius autem occupatur in aliis (EM 1577, $111 \mathrm{r})$.

90 Cf. Delisle 2008a, 88 and Meyer et al. 1999, 189-194 on Gessner's complete, long letter to Fuchs.

91 Innnumeris schedis notata potius, quam descripta [...] Et in capite plura forte quam in schedis habeo.

92 The five surviving fragments of plant descriptions from the very beginning of the planned Historia stirpium, of which we have analyzed the text on the Abrotonum plant above, originate from Gessner's legacy in the form reproduced by Schmiedel 1751a, 40-54, already revised by Wolf ( A Casp. Wolphio ... compositae). Gessner is consistently referred to by the third person (inquit Gesnerus). Yet the main question remains: if according to Schmiedel $1751 b$, XLIII Wolf actually had completed (perfecit) "80 very extensive chapters of the first book", why has Schmiedel published only five fragments? 
not fail to publish Gessner's text; Wolf's big mistake rather was that he had created the impression that such a text would already be available and was only waiting to be presented to the public. ${ }^{93}$ Statements such as Arber's bold assertion that Gessner "at the time of his death had already prepared a large part of the material for a general history" can now be dismissed..$^{94}$ Exactly the opposite seems to have been the case, and except for the drawings with their uncoordinated notes there was nothing to be published. ${ }^{95}$ Perhaps, it must be added, this was also one of the reasons why Crato von Krafftheim, who used to be too well-informed by Gessner to be fooled, did not react to Wolf's public appeal for collaboration.

\section{Final assessment of Wolf's efforts toward Gessner}

Opinions about Wolf's services for Gessner differ widely, and it is not easy to issue an unequivocal judgment. Wolf has entered into the history as the one who could not comply with his publicly effective announcement to edit Gessner's botanical legacy; but, on the other side, a number of researchers have expressed their understanding of Wolf's decision to sell the whole material to Joachim Camerarius the Younger in Nuremberg. From Schmiedel (1751b) over Hanhart (1824), Wolf (1858), Ley (1929) to Fischer (1966) ${ }^{96}$ Wolf's decision has been considered a reasonable and comprehensible step. Wolf's burdens as a town doctor, his sickly constitution and, above all, his extensive achievements as editor of Gessner's other writings and letters (see the bibliography under point "B 2") are all mentioned as reasons.

But there are also voices that were much more critical. Delisle ${ }^{97}$ quotes letters from the 1570s by Wolf's co-author Simmler to Abraham Musculus in Bern and Hieronymus Wolf in Augsburg, where a cautious criticism of Wolf's tardiness as editor is uttered, the same as in a letter from Gasser to Simmler. Above that, criticism must have been offered by some contemporaries when Wolf sold Gessner's collection of plant drawings to Camerarius

93 Wolf: "not only the very extensive and varied material is still extant and conserved for posterity, but also the mode of representation or order" - superesse tamen adhuc, et posteritati conservari, non materiam solum, quae amplissima est et varia, sed modum etiam seu ordinem $(\mathrm{P} 49 \mathrm{v})$.

94 Arber 1986, 111, referring to Wolf.

95 Simmler $(1574,142$ and 1583,168) lists various unpublished manuscripts that Wolf possessed from Gessner's legacy, but a plant history is not among them.

96 In detail: Schmiedel 1751b, XLIV, Hanhart 1824, 293, Wolf, R. 1858, 56, Ley 1929, 110, and Fischer 1966, 134.

97 Delisle 2008a, 263. 
II. According to Delisle ${ }^{98}$ this was perceived as "treachery". Regrettably, Delisle does not cite any details and does not give exact references.

The toughest judgment about Wolf was delivered by Hans H. Wellisch, who also had, as mentioned, uncovered Wolf's plagiarism affair immediately before Gessner's death. Wellisch believes that Wolf must have been "a man of mediocre talents and dubious character". ${ }^{99}$ To put it more mildly, one might say that Wolf was a diligent compiler rather than a scholar in his own right.

As the story after his sale of the botanical legacy shows, Wolf was not the only one who failed in the task of publishing an edition. None of the various later owners (buyers as well as heirs) succeeded, not even, in the middle of the eighteenth century, the Erlangen botanist Casimir Christoph Schmiedel, who enjoyed the massive support of the final owner, the physician-botanist, bibliophile and patron Christoph Jacob Trew from Nuremberg. Although Schmiedel's two volumes of Gessner's Opera botanica (1751a and 1771) were celebrated by some contemporaries, in reality they were very incomplete and extremely difficult to use. ${ }^{100}$ In the age of Linnaeus, the interest in Gessner's legacy came to an end and the former five volumes were torn apart: the first two volumes remained in Erlangen-Nuremberg, the last three were sold to Tartu University, Estonia. A third volume of Gessner's Opera botanica, as planned by Trew and Schmiedel, was never published. ${ }^{101}$

\section{Bibliography}

\section{A General literature}

Adam, Melchior, "Ioannes Crato a Crafftheim", in: Melchior Adam, Vitae Germanorum medicorum (Frankfurt \& Heidelberg 1620) 261-277

Alpers, Klaus, "Griechische Lexikographie in Antike und Mittelalter. Dargestellt an ausgewählten Beispielen", in: Hans-Albrecht Koch (ed.), Welt der Information. Wissen und Wissensvermittlung in Geschichte und Gegenwart (Stuttgart 1990) 14-38

98 Delisle 2008a, 117.

99 Wellisch 1984, 24.

100 See also the critical remarks by Hoppe (2004: 179) and some contemporary critique, documented by Henglein (2010: 74-75).

101 Also the latest edition of Gessner's botanical legacy by Steinmann and Zoller (1987-1991) was originally intended to contain a transcription and translation of all notes (Schmid et al. 1980). However, since such an undertaking would have included about 40 to 50 volumes and could not be financed, the project was abandoned and only a selection was published in the eight volumes of the so-called Faksimileausgabe (Martin Steinmann, personal communication July 2017); in volume 8 of the Faksimileausgabe, Zoller speaks of "at least 30 volumes" $(1980,7)$. 
Anonymous, Des Welt-berühmten Medici, Physici und Polyhistoris, Conradi Gesneri, Leben und Schrifften (Leipzig \& Zittau 1711)

Anderson, Frank J., German book illustration through 1500. Herbals through 1500. Volume 1 (New York 1983)

Anderson, Frank J., German book illustration through 1500. Herbals through 1500. Volume 2 (New York 1984)

Arber, Agnes, Herbals. Their origin and evolution. A chapter in the history of botany 1470-1670 (Cambridge ${ }^{3} 1986$ )

Arber, Agnes, The natural philosophy of plant form (Cambridge 1950)

Bauhin, Jean, De plantis a divis sanctisve nomen habentibus. Additae sunt Conradi Gesneri medici clarissimi epistolae hactenus non editae (Basel 1591)

Bauhin, Jean, De plantis Absynthii nomen habentibus (Montbéliard 1593)

Baumann, Dieter, "Psychiatrisches bei Conrad Gessner", in: Gesnerus 10 (1953) 123-150

Baumann, Brigitte, Baumann, Helmut and Baumann-Schleihauf, Susanne (eds.), Die Kräuterbuchhandschrift des Leonhart Fuchs (Stuttgart 2001)

Bäumer, Änne, Geschichte der Biologie. Volume 1: Biologie von der Antike bis zur Renaissance (Frankfurt 1991a)

Bäumer, Änne, Geschichte der Biologie. Volume 2: Zoologie der Renaissance Renaissance der Zoologie (Frankfurt 1991b)

Blair, Ann M., Too much to know. Managing scholarly information before the modern age (New Haven \& London 2010)

Bock, Hieronymus, Kreütter Buch. Darin Underscheid, Würckung und Namen der Kreütter so in Deutschen Landen wachsen [...]. 3 parts. (Strasburg 1546)

Bock, Hieronymus, De stirpium, maxime earum, quae in Germania nostra nascuntur [...] commentariorum libri tres. Translated by David Kyber, preface by Conrad Gessner (Strasburg 1552)

Braun, Lucien, Conrad Gessner (Geneva 1990)

Bretin-Chabrol, Marine and Leduc, Claudine, "La botanique antique et la problématique du genre", in Clio 29 (2009) 205-223

Brunfels, Otto, Contrafayt Kreüterbuch (Strasburg 1532)

Brüning, Volker Fritz, Die alchemistischen Druckwerke von der Erfindung der Buchdruckerkunst bis zum Jahre 1690 (Munich 2004)

Butler, Harold E., The Apologia and Florida of Apuleius of Madaura (Oxford 1909)

Camerarius, Joachim, De plantis epitome utilissima, Petri Andreae Matthioli Senensis, medici excellentissimi, etc. Novis plane, et ad vivum expressis iconibus, descriptionibusque longe et pluribus et accuratioribus nunc primum diligenter aucta, et locupletata (Frankfurt 1586a)

Camerarius, Joachim, Kreutterbuch deß hochgelehrten unnd weitberühmten Herrn D. Petri Andreae Matthioli (Frankfurt 1586b)

Camerarius, Joachim, Hortus medicus et philosophicus in quo plurimarum stirpium breves descriptiones, novae icones non paucae, indicationes locorum natalium, observationes de cultura earum peculiares, atque insuper nonnulla remedia euporista, nec non philologica quaedam continentur (Frankfurt 1588)

Coolidge, William Augustus Brevoort, Josias Simler et les origines de l'alpinisme jusqu'en 1600 (Grenoble 1904)

Dantz, Johannes, Tabula simplicium medicamentorum (Basel 1543) 
Dauser, Regina, Hächler, Stefan, Kempe, Michael, Mauelshagen, Franz and Stuber, Martin (eds.), Wissen im Netz. Botanik und Pflanzentransfer in europäischen Korrespondenznetzen des 18. Jahrhunderts (Berlin 2008)

Debus, Allen G., Man and nature in the Renaissance (Cambridge 1978)

Delisle, Candice, Establishing the facts. Conrad Gessner's epistolae medicinales between the particular and the general. Thesis (Ph.D.) (University of London 2008a)

Delisle, Candice, "Accessing nature, circulating knowledge. Conrad Gessner's correspondence networks and his medical and naturalist practices", in: History of universities 23 (2008b), 35-58

Ducourthial, Guy, Flore magique et astrologique de l'Antiquité (Berlin 2003)

Durling, Richard J., "Conrad Gesner's Liber amicorum 1555-1565”, in: Gesnerus 22 (1965) 134-159

Egmond, Florike and Kusukawa, Sachiko, "Circulation of images and graphic practices in Renaissance natural history: the example of Conrad Gessner", in: Gesnerus 73 (2016) 29-72

Egmond, Florike, “Animal drawings for Gessner's Historia animalium rediscovered in Amsterdam", in: Urs B.Leu and Mylène Ruoss (eds.), Facetten eines Universums. Conrad Gessner 1516-2016 (Zurich 2016) 155-162

Egmond, Florike, Eye for detail. Images of plants and animals in art and science, 1500-1630 (London 2017)

Elliott, Brent, "Ideas of classification", in: Brent Elliot (ed.), Flora. Federico Cesi's botanical manuscripts. 3 volumes (London 2015), vol. 1, 48-61

Etter, Walter, "Conrad Gessner als Paläontologe", in: Urs B.Leu and Mylène Ruoss (eds.), Facetten eines Universums. Conrad Gessner 1516-2016 (Zurich 2016) 175-184

Everett, Nicholas, The alphabet of Galen: Pharmacy from antiquity to the Middle Ages. A critical edition of the Latin text with English translation and commentary (Toronto 2012)

Fischer, Hans, Conrad Gessner (26. März 1516-13. Dezember 1565). Leben und Werk (Zurich 1966)

Fossel, Viktor von, Studien zur Geschichte der Medizin (Stuttgart 1909)

Friedrich, Udo, Naturgeschichte zwischen artes liberales und frühneuzeitlicher Wissenschaft. Conrad Gessners "Historia animalium" und ihre volkssprachliche Rezeption (Tübingen 1995)

Fuchs, Leonhart, "De usitata huius temporis componendorum miscendorumque medicamentorum ratione libri III", in: Leonhart Fuchs, Methodus seu ratio compendiaria perveniendi ad veram solidamque medicinam (Basel 1541) 319-540

Fuchs, Leonhart, De historia stirpium commentarii insignes (Basel 1542)

Fuchs, Leonhart, New Kreüterbuch (Basel 1543)

Fuchs-Eckert, Hans Peter, "Die Familie Bauhin in Basel", in: Bauhinia 6 (1977) $13-48$

Funk, Holger, "Describing plants in a new mode: the introduction of dichotomies into sixteenth-century botanical literature", in: Archives of natural history 41 (2014) 100-112

Funk, Holger, "Thomas Penny and Conrad Gessner: a revision of some longestablished chronological particulars", in: Archives of natural history 45 (2018) 166-169 
Genaust, Helmut, Etymologisches Wörterbuch der botanischen Pflanzennamen (Basel, Boston, Stuttgart 1983)

Gessner, Conrad, Succiduorum medicaminum tabula, quorum usus habetur reciprocus, Graece \& Latine, in: Conrad Gessner (ed.), Actuarius de medicamen torum compositione, Joan. Ruellio interprete (Basel 1540)

Gessner, Conrad, Historiae animalium liber I. de quadrupedibus viviparis (Zurich 1551)

Gessner, Conrad, Historiae animalium liber IV., de piscium et aquatilium animantium natura (Zurich 1558)

Gessner, Conrad, Mithridates. De differentiis linguarum tum veterum tum quae hodie apud diversas nationes in toto orbe terrarum in usu sunt (Zurich 1555)

Gessner, Conrad, De libris a se editis epistola. Ad Guilielmum Turnerum theologum \& medicum excellentiss. in Anglia (Zurich 1562)

Gessner, Conrad, De omni rerum fossilium genere, gemmis, lapidibus, metallis, et huiusmodi, libri aliquot (Zurich 1565)

Gessner, Conrad, Epistolarum medicinalium Conradi Gesneri, philosophi et medici Tigurini, liber quartus. Edited by Simon Gronenberg (Wittenberg 1584)

Gillet, Johann Franz Albert, Crato von Crafftheim und seine Freunde. Ein Beitrag zur Kirchengeschichte. 2 volumes (Frankfurt 1860-1861)

Gmelig-Nijboer, Caroline Aleid, Conrad Gessner's “Historia Animalium”. An inventory of. Renaissance zoology (Meppel 1977)

Goeing, Anja-Silvia, "Geeignet für Studenten der Philosophie, Medizin und Philologie': Gessners Unterrichtsmaterialien für die Hohe Schule in Zürich", in: Urs B. Leu and Mylène Ruoss (eds.), Facetten eines Universums. Conrad Gessner 1516-2016 (Zurich 2016) 43-52

Greene, Eward Lee, Landmarks of botanical history. Edited by Frank N. Egerton. Volume 2 (Stanford 1983)

Gunnoe, Charles D. and Shackelford, Jole, "Johannes Crato von Krafftheim (15191585). Imperial physician, irenicist, and anti-Paracelsian", in: Marjorie Elizabeth Plummer and Robin Barnes (eds.), Ideas and cultural margins in early modern Germany. Essays in honor of H. C. Erik Midelfort (Farnham \& Aldershot 2009) 201-216

Habermann, Mechthild, Deutsche Fachtexte der frühen Neuzeit. Naturkundlichmedizinische Wissensvermittlung im Spannungsfeld von Latein und Volkssprache (Berlin, New York 2001)

Hanhart, Johannes, Conrad Geßner. Ein Beytrag zur Geschichte des wissenschaftlichen Strebens und der Glaubensverbesserung im 16ten Jahrhundert (Winterthur 1824)

Harig, Georg, "Leonhart Fuchs und die theoretische Pharmakologie der Antike", in: Schriftenreihe für Geschichte der Naturwissenschaften, Technik und Medizin 3 (1966) 74-104

Harig, Georg, Bestimmung der Intensität im medizinischen System Galens (Berlin 1974)

Helmich, Egon, Die Briefe Konrad Gesners an Crato von Krafftheim nach der Briefsammlung von 1566 (recte 1577) (Düsseldorf 1938) 
Henglein, Dominik Klaus Michael, Casimir Christoph Schmidel (1718-1792) und seine Korrespondenz mit Johann Ambrosius Beurer (1716-1754) (ErlangenNürnberg 2010)

Hirsch, August, Biographisches Lexikon der hervorragenden Ärzte aller Zeiten und Völker. Volume 6 (Vienna \& Leipzig 1888)

Hoppe, Brigitte, Das Kräuterbuch des Hieronymus Bock. Wissenschaftshistorische Untersuchung (Stuttgart 1969)

Hoppe, Brigitte, "Botanik und Zoologie in der Zeit der Renaissance und des Humanismus", in: Ilse Jahn (ed.), Geschichte der Biologie. Theorien, Methoden, Institutionen, Kurzbiografien (Hamburg 32004) 161-195

Jaumann, Herbert, "Wolf, Caspar", in: Wilhelm Kühlmann (ed.), Killy Lieraturlexikon. Autoren und Werke des deutschsprachigen Kulturraumes. Volume 12 (Berlin \& Boston 2011) 529-530

Kempe, Michael, "Zwischen den Maschen. Die andere Seite der Korrespondenznetze", in: Regina Dauser et al., Wissen im Netz. Botanik und Pflanzentransfer in europäischen Korrespondenznetzen des 18. Jahrhunderts (Berlin 2008) 301-314

Kettler, Wilfried, Untersuchungen zur frühneuhochdeutschen Lexikographie in der Schweiz und im Elsass (Bern 2008)

King, Charles William, The natural history, ancient and modern, of precious stones and gems and of precious metals (London 1865)

Krajewski, Markus, Paper machines. About cards \& catalogs, 1548-1929 (Cambridge, MA \& London 2011)

Kusukawa, Sachiko, "The role of images in the development of Renaissance natural history", in: Archives of natural history 38 (2011) 189-213

Kusukawa, Sachiko, Picturing the book of nature. Image, text, and argument in sixteenth-century human anatomy and medical botany (Chicago 2012)

Lelli, Emanuele (ed.), Erasmo da Rotterdam: Adagi (Milan 2013)

Leu, Urs. B., "Konrad Gessner und die Neue Welt", in: Gesnerus 49 (1992) 279-309

Leu, Urs B., "Aneignung und Speicherung enzyklopädischen Wissens. Die LociMethode von Erasmus", in: Christine Christ-von Wedel and Urs B. Leu (eds.), Erasmus in Zürich. Eine verschwiegene Autorität (Zurich 2007) 327-342

Leu, Urs B., Conrad Gessner (1516-1565). Universalgelehrter und Naturforscher der Renaissance (Zurich 2016a)

Leu, Urs B., "The rediscovered third volume of Conrad Gessner's 'Historia plantarum'", in: Ann Blair and Anja-Silvia Goeing (eds.), For the sake of learning. Essays in honor of Anthony Grafton. Volume 1 (Leiden \& Boston 2016b) $415-422$

Leu, Urs B., "Conrad Gessner's Netzwerk", in: Urs B. Leu and Mylène Ruoss (eds.), Facetten eines Universums. Conrad Gessner 1516-2016 (Zurich 2016c) 61-74

Leu, Urs B., Keller, Raffael and Weidmann, Sandra, Conrad Gessner's private library (Leiden \& Boston 2008)

Ley, Willy, Konrad Gesner. Leben und Werk (Munich 1929)

Linnaeus, Carolus, Systema naturae (Amsterdam 1735)

Mattioli, Pietro Andrea, Opusculum de simplicium medicamentorum facultatibus (Venice 1569) 
Mayerhöfer, Josef, "Conrad Geßner als Bibliograph und Enzyklopädist", in: Gesnerus 22 (1965) 176-194

Meyer, Frederick G., Trueblood, Emily Emmart and Heller, John L. (eds.), The Great Herbal of Leonhart Fuchs De historia stirpium commentarii insignes, 1542 (Stanford 1999)

Miethaner-Vent, Karin, "Das Alphabet in der mittelalterlichen Lexikographie. Verwendungsweisen, Formen und Entwicklung des alphabetischen Anordnungsprinzips", in: Claude Buridant (ed.), La lexicographie au moyen âge (Lille 1986) 83-112

Milt, Bernhard, “Conrad Gessner's 'Historia plantarum' (Fragmenta relicta)", in: Vierteljahrsschrift der naturforschenden Gesellschaft in Zürich 81 (1936) 285-291

Milt, Bernhard, "Chemisch-alchemistische Heilkunde und ihre Auswirkungen in Zürich”, Vierteljahrsschrift der Naturforschenden Gesellschaft in Zürich 98 (1953) $178-215$

Müller, Clemens, “'Conrado Gesnero Philologo' - Gessners Beiträge zur klassischen Philologie", in: Urs B. Leu and Mylène Ruoss (eds.), Facetten eines Universums. Conrad Gessner 1516-2016 (Zurich 2016) 82-98

Müller, Peter O., Deutsche Lexikographie des 16. Jahrhunderts. Konzeptionen und Funktionen frühneuzeitlicher Wörterbücher (Tübingen 2001)

Nutton, Vivian, "Humoralism", in: William Bynum and Roy Porter (eds.), Companion encyclopedia of the history of medicine. Volume 1 (London 1993) 281-291

Nyffeler, Reto, "Gessner als Botaniker", in: Urs B.Leu and Mylène Ruoss (eds.), Facetten eines Universums. Conrad Gessner 1516-2016 (Zurich 2016) 163-174

Ogilvie, Brian W., The science of describing. Natural history in Renaissance Europe (Chicago and London 2006)

Peters, Manfred, "Conrad Gessner als Linguist und Germanist", in: Gesnerus 28 (1971) 115-146

Pfister, Arnold, "Die Pflanze und das Buch. Zweiter Teil. Aufstieg und Ausklang des Pflanzenbildes im Buchholzschnitt medizinisch-botanischer Werke des 16. und 17. Jahrhunderts", in: Librarium 8,3 (1965) 151-192

Rand, Mare, “'Ramulus cum flore melius pingitur in meis ...' Verschollene Pflanzenzeichnungen aus dem Gessner-Nachlass in der Universitätsbibliothek Tartu/ Dorpat", in: Hanspeter Marti (ed.), Kulturaustausch. Baltisches Echo auf Gelehrte in der Schweiz und in Deutschland. Freundesgabe für Arvo Tering (Cologne 2014) 13-48

Rand, Mare, Ajaloolise kultuurivara jälgedel. Konrad Gessneri taimejoonistused Tartu Ülikooli Raamatukogus (Tartu 2015) (Traces of historical cultural assets. Konrad Gessner's plant drawings at Tartu University Library; English summary pp 117-120)

Raven, Charles E., English naturalists from Neckam to Ray. A study of the making of the modern world (Cambridge 1947)

Rein, Wilhelm, Das Privatrecht und der Civilprocess der Römer. Von der ältesten Zeit bis auf Justinianus. Ein Hülfsbuch zur Erklärung der Classiker und der Rechtsquellen für Philologen und angehende Juristen (Leipzig 1858) 
Riddle, John M., "Dioscorides", in: F. Edward Cranz and Paul Oskar Kristeller (eds.), Catalogus translationum et commentariorum. Volume 4 (Washington 1980) $1-143$

Riddle, John M., Quid pro quo: studies in the history of drugs (Farnham 1992)

Rüetschi, Kurt J. "Der Zürcher Arzt Georg Keller und seine Studienzeit in Lausanne (1549/50)", in: Zwingliana 43 (2016) 161-176

Sauerhoff, Friedhelm, Pflanzennamen im Vergleich. Studien zur Benennungstheorie und Etymologie (Stuttgart 2001)

Scarborough, John, Pharmacy and drug lore in antiquity (Aldershot 2009)

Schmid, Karl, Steinmann, Martin and Zoller, Heinrich, "Conradi Gesneri Historia Plantarum", in: Librarium 23 (1980) 96-115

Schmidt, Max C. P., "Eberraute", in: Paulys Realencyclopädie der classischen Altertumswissenschaft 2.2 (1905) 1894-1895

Schmiedel, Casimir Christoph (ed.), Conradi Gesneri Opera botanica per duo saecula desiderata. Volume 1 (Nuremberg 1751a [recte 1753])

Schmiedel, Casimir Christoph, "Historia operis", in: Casimir Christoph Schmiedel (ed.), Conradi Gesneri Opera botanica per duo saecula desiderata. Volume 1 (Nuremberg 1751b [recte 1753]) XLI-LVI

Schnalke, Thomas (ed.), Natur im Bild. Anatomie und Botanik in der Sammlung des Nürnberger Arztes Christoph Jakob Trew (Erlangen 1995)

Selosse, Philippe, "Peut-on parler de classification à la Renaissance? Les concepts d'"ordre" et de "classe" dans les ouvrages sur les plantes", in: Seizième siècle 8 (2012a) 39-56

Selosse, Philippe, "The role of Clusius (1526-1609) as translator in the emergence of a taxonomic terminology in botany" in: Harold Cook and Sven Dupré (eds.), Translating knowledge in the early modern Low Countries (Berlin, Zurich, Vienna 2012b) 349-368

Simmler, Josias, Vita clarissimi philosophi et medici excellentissimi Conradi Gesneri Tigurini (Zurich 1566)

Simmler, Josias (ed.), Bibliotheca instituta et collecta primum a Conrado Gesnero (Zurich 1574, 1583)

Springer, Katharina B. and Kinzelbach, Ragnar K., Das Vogelbuch von Conrad Gessner (1516-1565). Ein Archiv für avifaunistische Daten (Berlin 2008)

Taplin, Mark, "Josias Simler and the Fathers: The 'Scripta veterum latina' (1571)", in: Zwingliana 38 (2011) 67-152

Tortzen, Chr. Gorm, "Male and female in Peripatetic botany", in: Classica et mediaevalia 42 (1991) 81-110

Touwaide, Alain, "Quid pro quo. Revisiting the practice of substitution in ancient pharmacy", in: Anne van Arsdall and Timothy Graham (eds.), Herbs and healers from the ancient mediterranean through the medieval west (Farnham 2012) $19-61$

Treviranus, Ludolph Christian (ed.), Caroli Clusii et Conr. Gesneri Epistolae ineditae (Leipzig 1830)

Treviranus, Ludolph Christian, Die Anwendung des Holzschnittes zur bildlichen Darstellung von Pflanzen nach Entstehung, Blüthe, Verfall und Restauration (Leipzig 1855) 
Trew, Christoph Jacob, "Vita Conradi Gesneri Tigurini philosophi et medici summi", in: Casimir Christoph Schmiedel (ed.), Conradi Gesneri Opera botanica per duo saecula desiderata. Volume 1 (Nuremberg 1751[recte 1753]) I-XL

Vischer, Manfred, Bibliographie der Zürcher Druckschriften des 15. und 16. Jahrhunderts (Baden-Baden 1991)

Wellisch, Hans H., Conrad Gessner. A bio-bibliography (Zug 1984)

Wenning, Svenja, Joachim II. Camerarius (1534-1598). Eine Studie über sein Leben, seine Werke und seine Briefwechsel (Duisburg 2015)

Wolf, Rudolf, Biographien zur Kulturgeschichte der Schweiz. Volume 1 (Zurich 1858)

Wyß, Georg von, "Simmler, Josias", in: Allgemeine Deutsche Biographie 34 (1892) 355-358

Zadoks, Jan C., Crop protection in medieval agriculture. Studies in pre-modern organic agriculture (Leiden 2013)

Zoller, Heinrich and Steinmann, Martin (eds.), Conradi Gesneri Historia plantarum. Gesamtausgabe. Volume 1 (Dietikon-Zürich 1987)

Zoller, Heinrich and Steinmann, Martin (eds.), Conradi Gesneri Historia plantarum. Gesamtausgabe. Volume 2 (Dietikon-Zürich 1991)

Zoller, Heinrich, Steinmann, Martin and Schmid, Karl (eds.), Conradi Gesneri Historia plantarum. Faksimileausgabe. 8 volumes (Dietikon-Zürich 1972-1980)

Zoller, Heinrich, "Konrad Geßner als Botaniker", in: Gesnerus 22 (1965) $216-227$

Zoller, Heinrich, "Zum Wandel der Pflanzendarstellung während der Renaissance. Vom Beginn des 15. Jahrhunderts zu Leonardo da Vinci, Albrecht Dürer und Conrad Gessner", in: Bauhinia 9 (1989) 109-123

Zoller, Heinrich, "Vorwort zur Gesamtausgabe", in: Heinrich Zoller and Martin Steinmann (eds.), Conradi Gesneri Historia plantarum. Gesamtausgabe. Volume 2 (Zurich 1991) 9-10

\section{B Publications by Caspar Wolf}

Note: As to Wolf's books printed at Zurich ("Offizin Froschauer"), see the overview of references with detailed specifications to the individual works in Vischer 1991, 534.

\section{B. 1 As autonomous author}

Wolf, Caspar, Caspari Vvolphii Tigurini medici et philosophi $\mathrm{Y} \Pi \mathrm{O} \Sigma \mathrm{XE} \Sigma \mathrm{I} \Sigma$, sive de Conradi Gesneri stirpium historia ad Ioan. Cratonem, S. Caes. Maiest. medicum excellentiss. Pollicitatio, pp 46-56 in Josias Simmler, Vita clarissimi philosophi et medici excellentissimi Conradi Gesneri Tigurini (Zurich 1566a/1566b) [The second edition " $1566 \mathrm{~b}$ " is minimally different from the first one.]

Wolf, Caspar, Diodori Euchyontis de polychymia libri quatuor (Zurich 1567)

\section{B. 2 As editor of Gessner's writings}

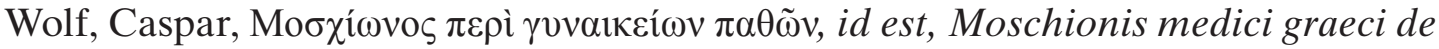
morbis muliebribus liber unus cum Conradi Gesneri viri clariss. scholiis \& emendationibus (Basel 1566a) 
Wolf, Caspar, Gynaeciorum, hoc est, De mulierum tum aliis tum grauidarum, parientum \& puerperarum affectibus \& morbis (Basel 1566b)

Wolf, Caspar, Euonymus. Conradi Gesneri, medici et philosophi Tigurini de remediis secretis (Zurich 1569a)

Wolf, Caspar, Euonymus. Conradi Gesneri, medici et philosophi Tigurini de remediis secretis (Zurich 1569b) [with a different title page and additionally a reply by Wolf to Antoin Valet, cf. Wolf B. 3, 1569 below]

Wolf, Caspar, Epistolarum medicinalium Conradi Gesneri philosophi et medici Tigurini libri III. His accesserunt eiusdem aconiti primi Dioscoridis asseveratio, et de oxymelitis elleborati utriusque descriptione et usu libellus (Zurich 1577)

Wolf, Caspar, Der erste Theil dess köstlichen unnd theuren Schatzes Euonymi Philiatri (Zurich 1582)

Wolf, Caspar, Aphorismorum Hippocratis methodus nova, ab Achille P. Gassaro Lindaviensi medico primum quinque libris distincta: deinde vero Conradi Gesneri Tigurini medici opera illustrata (St. Gallen 1584a)

Wolf, Caspar, Dominici Massarii Vincentini De ponderibus \& mensuris medicinalibus libri tres. Ex Graecis, Arabicis et Latinis rei medicae scriptoribus diligentissime conscriptus, non medicis modo, sed omnibus literarum linguarumque studiosis perutilis futurus / ante annos 60. in Italia ediditus primum, nunc vero ab innumeris mendis Conradi Gesneri opera repurgatus, huic accedunt etiam alia quaedam eiusdem argumenti, quorum titulos post epistolas positos reperies (Zurich 1584b)

Wolf, Caspar, Conradi Gesneri Tigvrini philosophi et medici clarissimi Physicarum meditationum, annotationum \& scholiorum lib. V (Zurich 1586)

Wolf, Caspar, De stirpium collectione tabulae tum generales, tum per duodecim menses (Zurich 1587a). The second part has a separate title page: Conradi Gesneri De partibus et differentiis plantarum physica synopsis.

Wolf, Caspar, Historiae insectorum libellus, qui est de scorpione. In: Historiae animalium lib V. qui est de serpentium natura. Edited by J. Carron (Zurich 1587b)

Wolf, Caspar, Schlangenbuoch das ist ein grundtliche und vollkommne Beschreybung aller Schlangen, so im Meer, süssen Wassern und auff Erden jr Wohnung haben, sampt der selbigen Conterfactung. erstlich durch den hochgelehrten weytberümpten Herrn D. Conrat Gessnern zuosamen getragen unnd beschriben unnd hernaher durch den wolgelehrten Herrn Jacobum Carronum gemehrt und in dise Ordnung gebracht; an yetzo aber mit sondrem Fleyss verteütscht (Zurich 1589)

Wolf, Caspar, Thesaurus medicinae practicae ex Conradi Gesneri schedis autographis et celebrium sui aevi medicorum epistolis (1596, unpublished)

Wolf, Caspar, Köstlicher Artzneyschatz dess wolerfarnen unnd weythberümpten Evonymi Philiatri (Zurich 1608)

\section{B. 3 As editor/translator of other writings}

Wolf, Caspar, Kalender oder Lassbüchlin sampt der Schrybtafel, Mässen und Jarmarckten, uffs Jar $<n n>$ (Zurich 1563-1593) (Titles slightly varying.)

Wolf, Caspar, Viaticum novum. De omnium fere particularium morborum curatione liber / authoris innominati quidem, sed longe doctissimi, vere aureus \& incom- 
parabilis; nunc primum in lucem editus per Casparum Vvolphium, medicum, physicum Tigurinum (Zurich 1565). Second edition 1578. (See Wellisch 1984, 97: the second edition has a new chapter "Ad lectorem admonitio" with the admission that Jacques Houllier was the true author of the Viaticum novum of 1565 and not Wolf, cf. Wolf B.2, 1569b above.)

Wolf, Caspar, Alphabetum empiricum, sive, Dioscoridis et Stephani Atheniensis philosophorum et medicorum, de remediis expertis liber, iuxta alphabeti ordinem digestus (Zurich 1581)

Wolf, Caspar, Gynaeciorum sive de mulierum affectibus commentarii Graecorum, Latinorum, barbarorum, iam olim et \& nunc recens editorum. 4 volumes (Basel 1586-1588)

\section{Conrad Gessner: Botanical publications during his liftime}

Note: In parentheses [] the enumeration by Wellisch 1984 is specified, who also provides the exact, extensive titles and some more information.

Gessner, Conrad, Historia plantarum et vires ex Dioscoride, Paulo Aegineta, Theophrasto, Plinio, \& recentioribus Graecis, iuxta elementorum ordinem (Basel 1541) [A 3.1]

Gessner, Conrad, Catalogus plantarum Latine, Graece, Germanice, \& Gallice (Zurich 1542) [A 8.1]

Gessner, Conrad (ed.), Hieronymus Tragus, De stirpium ... facultatibus. (Strasburg 1552) [A 33]

Gessner, Conrad (ed.), David Kyber, Lexicon rei herbariae trilingue. Including Gessner's Tabulae stirpium (Strasburg 1553) [A 35]

Gessner, Conrad, De raris et admirandis herbis. Including Gessner's Descriptio montis Fracti, sive montis Pilati (Zurich 1555) [A 37/38.1]

Gessner, Conrad, De stirpium aliquot nominibus vetustis ac novis (Basel 1557) [A 45.1]

Gessner, Conrad (ed.), Valerius Cordus, In hoc volumine continentur Valerii Cordi Simesusii Annotationes in Dioscorides. Eiusdem Cordi historiae stirpium lib. IIII posthumi. Including Conrad Gessner, De hortis Germaniae (Zurich 1561) [A 51.1]

Gessner, Conrad (ed.), Valerius Cordus, Stirpium descriptionis liber quintus (Zurich 1563) [A 59] 


\section{(Part II: Translation)}

Caspar Wolf, YПO $\mathrm{XE} \Sigma \mathrm{I} \Sigma$, sive de Conradi Gesneri stirpium historia ad Ioan. Cratonem, S. Caes. Maiest. medicum excellentiss. Pollicitatio, pp 42-52 (46-56 in the amended second edition of the same year) in Josias Simmler, Vita clarissimi philosophi et medici excellentissimi Conradi Gesneri Tigurini. Zurich 1566.

Title page of Simmler's Vita Conradi Gesneri (1566a and 1566b)

\section{I T A \\ CLARISSIMI PHI" LOSOPHIET MEDICI EX \\ CELIENTISSIMI CONRADI GESA NER I Tigurini, conferipta à I O S I A $S$ INI LER O Tigurino.}

I T E M, Epiftold Ge fneride libris à fe editis. Et $C_{\text {are }}$ mina complure in obitum eius conferipta.

HIS ACCESSIT

C 5 P $\mathrm{P}$ I V VOLPHII Tigurini Mes dici \& Philofophi H Y p O S C H E S S , fiue, de C ON. GE SNBRI Stirpium hiftoria ad IOAN. C R A T O N E M S. C AB S.Maieft,medicumexsellentir, Pollicitatio.

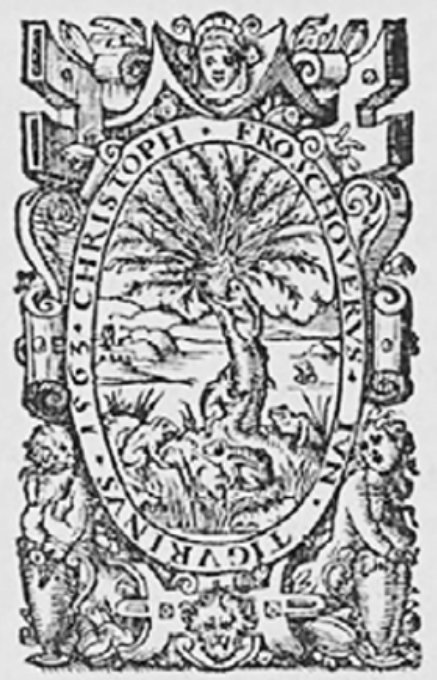

TIG VR I Excudebat Frofchoutrus, 15660 


\section{CASPARI VVOL: PHII TIGVRINI MEDICI ET PHILOSOPHI THO YE DE CONRADI GESNBRI STIRPIVM hiftoria ad IOAN. CRATONEM S.Car. Maieft,medicum excellentifs. Pollicitatio.}

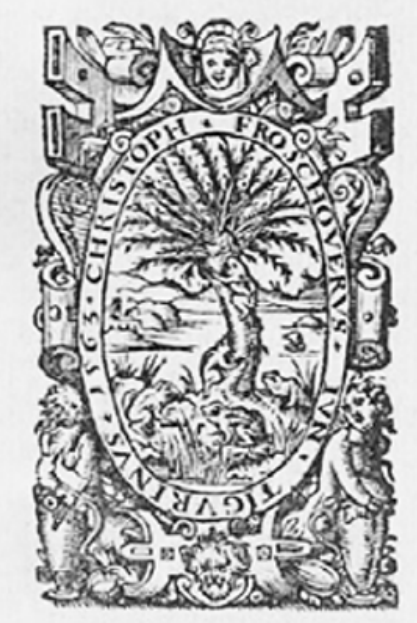

T I G V R Excudebat Frofchouerus, 1566.
Title page of Wolf's open letter to Crato von Krafftheim in the amended second edition (1566b, p. 46r) within Simmler's Vita Conradi Gesneri; missing in the first edition (1566a). ${ }^{102}$ The title reads:

"Caspari Vvolphii

Tigurini medici et philosophi ' de Conradi Gesneri stirpium historia ad Ioan(nem) Cratonem S(acratissimae) Caes(aris) Maiest(atis) medicum excellentiss(imum) Pollicitatio.”

\section{Gessner's urgent request on the sickbed ${ }^{104}$}

[46r] Promise of the Zurich physician and philosopher Caspar Wolf concerning Conrad Gessner's history of plants to Johannes Crato, most excellent physician of His Holiest Imperial Majesty.

102 The pagination in recto-verso mode is shifted by 4 in the two editions; thus, for example, fol. " $43 \mathrm{v}$ " in $1566 \mathrm{a}$ is fol. " $47 \mathrm{v}$ " in the $1566 \mathrm{~b}$ edition, and vice versa. On other minor differences of the generally identical editions, see Pfister 1965, 191. My translation is based on the second edition. As to the references, see the bibliography in my complementary essay on Wolf.

103 The title on the overall title page has in transliterated Greek Hyposchesis, on the separate

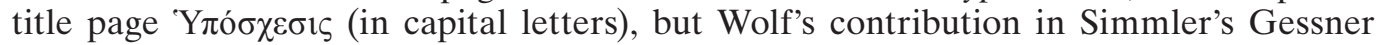
biography of 1566 is commonly quoted under its Latin equivalent "Pollicitatio".

104 All chapter headings, structuring in paragraphs and footnotes are from the present translator. 
Since both your outstanding character and your excellent scholarship and wisdom - which undoubtedly caused the Divine Emperor Ferdinand [I] ${ }^{105}$ to make you his body physician - have been in many ways familiar and wellknown to me and for a long time have led me equally to adore as well as to love you, I have often and much thought to myself, very honoured Crato, to prove this by entering into a kind of obligation towards you.

A further incentive added to this desire and zeal on my part is the tireless and frequent exhortation to do so by the most scholarly Conrad Gessner of blessed memory, whose premature death we all grievously mourn, since with him a loss is connected to the whole Republic of Letters. What I at least now finally understand is that he did this so that if, in the course of working on an important matter, something unforeseen had happened, he had made clear what a great support to my attempts and plans I could find in you.

And indeed, this case occurred more quickly than anybody could expect. On the $9^{\text {th }}$ of December (1565), when Gessner felt he was seriously ill and afflicted and seized by a malignant carbuncle, and no one could judge exactly which outcome the disease would take, [46v] he disclosed to me his plan in many words enlarged upon it. At first he showed me not only in its respective place the many and different materials ${ }^{106}$ for the composition of his History of plants (Historia stirpium) ${ }^{107}$ that he had scattered here and there in his "Museum", ${ }^{108}$ as it is usually the case with an abundance of activities, but time and again he suggested to me at length and urgently that I should take care of it. And although Gessner had already indicated to me earlier, when he used my services to arrange this matter and to read through some books of similar kind, by which way and plan such a great work could in his view be carried out, now that he thought he had to leave this to me, he showed me everything more completely and in detail.

And since he regarded this very history of plants as being necessary not only for physicians and philosophers, but also useful for the doctors of other

105 After the death of Ferdinand I (1503-1564) Crato in 1565 became court physician of Ferdinand's son and successor to the throne Maximilian II (1527-1576).

106 Wolf uses the term suppellectilem. In classical Latin, supellex, supellectilis means household utensils, stuff, furniture, goods; stock, store, but not bequeathment or legacy in the legal sense which would be legatum.

107 It should be noted that Wolf (and Gessner himself) calls the prospective work everywhere Historia stirpium (like Fuchs' great herbal of 1542), not "Historia plantarum", as it is today commonly cited (for instance in Heinrich Zoller's contributions). The semantic difference between plantae and stirpes (from sternere, to spread out) is minimal in practice and has no equivalent in English; in German it would be Pflanzen ("something set", a seedling or graft) as opposed to Gewächse ("something grown (by itself)"). Thus linguistically Gessner's and Wolf's stirpes rather than plantae precisely corresponds to the term pvió used by Theophrastus in the titles of his two great botanical studies.

108 On Gessner's natural history collection, see Leu 2016a, 190-194. 
arts and faculties, which for many years had been exceedingly desired by the greatest and most erudite of men, he asked me (what he ought to have demanded in his own right) that I might without concern undertake to execute this difficult, yet useful and longed for work under his name, if the Lord were to call him out of this life.

And this can be attested by many other people as well, as it is clear and striking proof that at the same time he set during his lifetime, when of a sound mind, a certain price for the entire botanical material, including the herbarium, all the sheets and the necessary books. And although, above all others, he was admirably distinguished by such an excellent spirit and insight that he could duly make a judgment of anyone, I thought that thereby something had impaired his impartiality which most other people usually encounter, namely that out of a certain kind of love and benevolence (as I have not only once experienced in a special way) he had bestowed on me more than I could actually cope with.

I was put into such embarrassment by his speech and desire that I indecisively vacillated for a long time between hope and doubt, and did not quite know what to answer to this unexpected request. Now, as he noticed my wavering and hesitation in answering, he gave me the courage to a certain degree not to doubt that his friends would assist me with help and advice, being men distinguished by learning and humanity, [47r] whose willingness he had won partly by services, partly by virtue of their own good nature, and which he had already received from them in his endeavours and actions as advisers and patrons.

This speech excellent doctor, I say, was what encouraged me so much that I removed all the hindrances which seemed to be in my way, and yielded to his desire, no matter how difficult, especially since he was dying. For all to whom nothing human is alien know how unfair and devoid of any humanity it is to refuse a just and amicable desire of friends who are about to pay their debts to nature. And now, after these things had been negotiated and concluded between us during those four days in which he had fought with the disease, he finally passed away in the eleventh hour of the night on the fifth day, which was the 13th of December, spiritually and calmly.

When, after his death, his entire literary material had been transferred to me according to the agreement, and after having arranged this chaos as best it could be, I found it particularly necessary to declare what in the near future can be expected from this long-awaited history of plants, now brought to daylight by means of a public commitment.

I felt compelled, however, to write to you, most learned Crato, partly so that I could amicably receive the humanity and kindness through which you are 
attached to all devotees of literature and science, and at the same time to satisfy my desire; but partly so that through you all may know what posterity owes to the many and great monuments of the spirit and work of our Gessner and can expect from this work. Indeed, you are now in a position in which so many thousands of people are involved, as well as you also wielding such an authority, that all eyes seem to be directed solely at you.

\section{Content and purpose of the botanical legacy}

Even though there are many different sheets, and these are very beautiful and of great utility, the first parts (of the legacy), in any case, will be dedicated to botany. As soon as this history will be completed, however, it will be able to supply not (only) a sketch but a history of a large part of the plant world and of rural life, so that it will be especially useful for all physicians, philosophers, natural scientists, and philologists [47v] since it will be diverse,

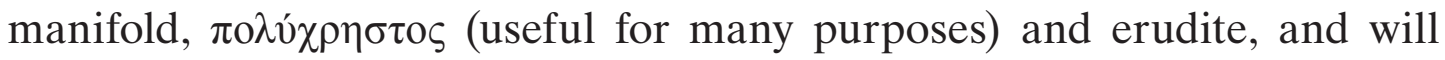
encompass many new, subtle, difficult and exquisite things.

Since the doctrine of the plants, as well as the thing itself, ${ }^{109}$ is considered to the present day by almost all men to be infinite, partly because of the enormous number and because of the great difference between the individual plants, and partly also because of the great variety of places where they grow (which to observe and to traverse individually, exceeds both the lifetime and the work of a single person), it seems as if this immensity has been reduced to a manageable number solely by the effort, the zeal, and the work of Gessner. He had collected such a number of plant pictures, which, according to a general judgment were so different among themselves that in future, as someone believed not without reason, no further (plant pictures) would be needed in the whole world.

But also this difficulty, which was caused by the diversity of the places of his work, was overcome partly by own journeys to a number of far-off places, which he undertook not only once at the risk of his life, ${ }^{110}$ but partly also by the generosity of learned men who travelled to where he himself could not travel for the sake of the health of his body and because of other disturbances; so that now rare and unique plants from almost the whole world seem to be gathered in this one place. ${ }^{111}$

109 That is, the plant world itself as opposed to the doctrine of it.

110 On Gessner's botanical excursions, see Leu 2016a, 264-271.

111 That is, in Gessner's home and garden in Zurich. 
Since Gessner had over a period of almost twenty years (as from his youth on, he was led to this study by a natural impetus) collected a great number of plant pictures with great judgment, especial diligence and extreme zeal, supported by the efforts, nighttime work and gifts of many friends from Italy, Germany and France, through which the collection had grown to 1,500 different pictures. ${ }^{112}$ And there is no doubt, in view of how diligent and thorough an explorer of nature he was, that if only the Lord had granted him a longer life, he would have brought much more together within the two years in which he hoped to complete this work, so that this natural history would undisputedly in many respects have surpassed the writings of all ancient and modern writers in this field.

And the present work has not only this advantage, but thanks to our Gessner, by means of mutual and careful comparison (as far as time allowed) of the ancient authors who have treated this matter - that is, Theophrastus, Dioscorides, Galen, Pliny, especially the Arabs, as well as some others - the controversies and conflicting opinions about the names of plants or their descriptions are in a large part reconciled and restored. And perhaps (as I often remember him), there is so far no one in this type of study who has done as much as he himself. And that this is indeed the case, provided that the Almighty God felicitously supports our efforts, the thing itself will attest to.

Yet how much this (planned work) will be useful in the future, and how necessary, is understood only by those who know that these (just mentioned) authors have laid the foundations and first principles for this part of the natural science, and that no one is successful who has not first dealt with it thoroughly. But apart from these authors, Gessner has consulted more than 200 others according to their suitability in composing this natural history, of which he has mostly collected and examined himself; a certain part, however, I [had gathered] at his direction. Anything that was useful to this subject was fully described, or at least briefly noted, in order to retrieve it later.

But there are many other (authors) who are to be studied: from the ancient physicians and philosophers most of Hippocrates, of Galen in particular De paratu facilibus ${ }^{113}$ of Averroes Collegit and of Aristotle Problemata, etc. The most important among the more recent writers are (Johannes) Manardus, (Aloysius) Mundella, Matthiolus, the Epistolae medicinales of (Johannes) Langius, the Consilia medica of (Bartholomaeus) Montagnana,

112 See also the explanations on this topic in my complementary essay.

113 Commonly known as De remediis parabilibus libri III. 
and some others. There are also some poets to be considered. Up to this point the outstanding Gessner has expanded the history of plants with great zeal and unremitting effort.

\section{The images}

The same scrupulousness was applied by Gessner while painting the plants and imitating their appearance in life. About 150 of them have already been perfectly and elaborately completed and executed by the author himself ${ }^{114}$ with such artistry and zeal, that his pictures rightly can be said what Pliny ${ }^{115}$ reported of the pictures of the famous painter Zeuxis, who indeed had portrayed grapes so skilfully that the birds would have flown to them as if they had been perfectly genuine; or what is handed down about Apelles, who would have drawn a mare true to life with such great craftsmanship, or similarly a bitch, that horses passing by whined and dogs barked. [48v] But how of much this is true is proven by the pictures attached at the end (of the present work).

The other plants drawn true to life, however, as Gessner found them in his own garden and partly also in the gardens of friends or other people, and which are painted with his own colours on paper and at great expense, he left behind at his death among the other fragments of his herbarium: partly for his own pleasure, partly so that they later could serve as perfect models for the woodcuts, but partly so that to the printed, finished work also colours could easily be added for those people who were willing to spend much more money on the purchase. If, however, he had no plants at his disposal to draw them true to life, he time and again asked friends urgently to send him plants accurately cut to size on paper. Still many plants of this kind remain, which must yet be requested from friends.

And while, regarding the proportion and size of the pictures, so far it has not been sufficiently taken into account by those who were concerned with the representation of plants, that on the one hand the buyer (of the book) would not be financially burdened, and on the other hand the one who is studying the pictures would not obtain dissimilar, scale-mismatched images (i.e. the

114 Examples are provided by Wolf in his Appendix (p. 10) below and in Wolf 1577. Cf. Gessner's letter to Theodor Zwinger of 26 November 1565 (Wolf 1577, 113r): "I am very anxious to represent in all plants these three parts (flower, fruit, root) true to nature. From them, the properties and affinities (naturae \& cognationes) are better to be seen than from the leaves of the plants." On Gessner's special attention to botanical details, see also Egmond 2017, 128, 177-181; Zoller 1989. In general, see Arber 1950.

115 Pliny, Naturalis historia 35.36.64. 

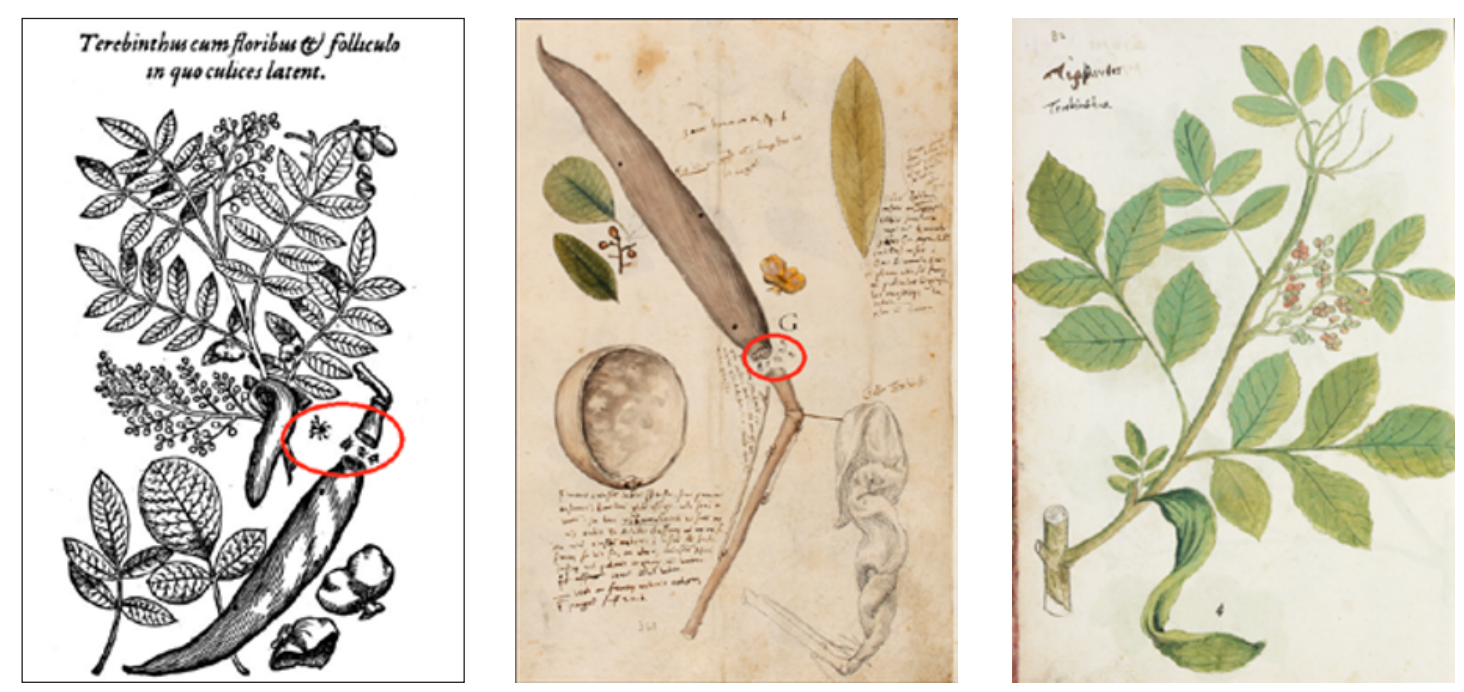

Figure 1: Images of the terebinth plant; see also the detailed explanation on p. 93.

largest as well as the smallest plants are depicted as the same size). The most circumspect and wise Gessner provided for the largest plants, that is, for those which reach four cubits, or even exceed them, the greatest format, namely six Roman inches, and consequently for those two cubits high, three inches, for those three cubits high, four and a half inches, etc., ${ }^{116}$ but for the smaller ones nearly the same format so that the smaller and therefore more difficult to recognize images would not be problematical. Of this kind we will add some pictures below. ${ }^{117}$

Moreover, because the individual parts belonging to the plants are reproduced within the entire picture only in a very reduced manner, in a way that they were neither delicately drawn as appropriate by any painter, nor could possibly be recognized by the observer, Gessner wanted to enlarge some parts, such as the flower or the seed, the fruit or the leaf, etc., beside the main picture with the whole plant. Also the interior of the fruit, as well as in some plants the seeds, should sometimes be observable in an anatomical manner. How this anatomical view looks like, we shall exhibit below (Figure 1) by means of the fruit of the terebinth, whose follicle, in which midges are hidden, is painted separately [49r] and cut up into parts, so that the interior can also be seen.

And regarding the formats (of the pictures) it is essential that they are adapted to the different large and small book formats. And so it will also be wholly appropriate for the work of Theophrastus, Dioscorides, and

116 In Roman measures, a cubitum, "elbow" or cubit, was about $45.72 \mathrm{~cm}$ long, a pollex, "thumb" or inch, exactly $2.54 \mathrm{~cm}$.

117 See Wolf's Appendix (p. 10) below. 
Pliny, who are treated with great care by me, after having been improved by Gessner in innumerable places, and explained by definite commentaries. For it does not require larger formats, if a small format with an aptly and truthfully drawn picture is sufficient for the reader and the viewer.

But also the handling of illustrations has to be defined in order not to be a burden on the buyer by this alone. If someone wants to trace the individual plants meticulously, and also wants to present a picture of the common plants which are everywhere and are known (although in the different regions other plants are common and known) and in which no error is possible, the number would swell to two or three thousand and increase the costs. Since the author (Gessner) was anxious to avoid this inconvenience, he thought of passing over the plants which he considered ordinary species, or of bringing together in one picture those that seemed to be related. This has also been observed by him in several species of the absinthe reproduced below, since they are very different from each other. ${ }^{118}$

Gessner recognized that in almost every plant certain differences of sex (sexus) are to be found, ${ }^{119}$ and he also made assumptions about flower, leaf, root, flavour, fragrance or faculties, and, above all, about the similarity of seed and fruit; but if they differed little, he did not consider it necessary to make this clear in the picture. Yet where there is a remarkable difference, he did not suppress it in any way, or want it to be passed over in the picture or drawing.

And so far, we have followed, at least in general, as well as what is possible what is to be hoped for from this work, and what the author until now has presented. Finally, we have also explained by a fairly cohesive presentation the meaning, quantity and quality of the images which will be used in this book.

\section{General set-up and arrangement}

Now, however, we wish to reproduce the rather complex arrangement of the whole work, so that all recognize that, even if the extremely skilled and astute $[49 \mathrm{v}]$ author of this work has been torn from us by fate prematurely,

118 See woodcut no. 6 in the Appendix.

119 In the Latin and German herbals of the sixteenth century, the terms sexus ("Geschlecht") or masculus/feminus ("männlich/weiblich") were not used in the later Linnaean sense but rather in the tradition of antiquity (Theophrastus) in order to indicate externally quite different "genera" (large versus small ones, strong versus slender ones and so on) of the same plant, see e.g. Bretin-Chabrol and Leduc 2009 or Tortzen 1991. For a pictorial example, see Figure 3. 
not only will the very extensive and varied material still extant be conserved for posterity, but the mode of representation or order to be used will be recognized as an excellent instrument of this future work, of which the author would undoubtedly have made use if he had lived longer.

And although Gessner, initially, when he conceived a plan as to how he was about to arrange everything, considered whether he was to follow Dioscorides, who dealt with the locality and, as it were, the species, divided into wild and cultivated plants, types of grains, legumes, spices, hot and cold white meats, and other distinctions of this kind; he also considered whether he should first collect about each plant all that the ancient authors Dioscorides, Hippocrates, Galen, Pliny, Avicenna, and many others had reported. Afterwards, however, with additions partly from individual recent authors, and partly from his own observations, Gessner finally decided to organize and explain each topic in alphabetical order, which he had used before in his Historia animalium, following the example of Galen and the highly learned Fuchs. ${ }^{120}$ Gessner was partly drawn to this plan because he had previously arranged numerous sheets in this way and so could use the work of other scribes more easily, but partly also because the future book should be constructed in the manner of a lexicon, so that not only physicians, but also other users could easily find what they were looking for.

In addition, Gessner has also for a time dealt with the question of whether it would be better or more expedient to summarize everything in a single volume, or to divide it into different volumes because of the differences in matter. And since he would have written extensively, comprehensively and carefully about everything that can be said about plants, for which reason the book was intended to be partly a grammatical one in which names and etymologies were explained from the Greek, Latin, Arabic, Hebrew etc., but also in part a natural philosophy or natural history, which would include descriptions of the individual plants, their genera and species, the time at which they bloom, germinate, produce seeds or fruits, and much more of this kind. However, in part it was also a medical book that chiefly would have been concerned with the powers [50r] and effects of the plants, as they are used for food or medicine - (because of this broad range,) he again pondered whether it would not be fairly appropriate to make a subdivision into three independent books.

At times Gessner, however, thought he was to summarize the subject in two volumes, the first of which would contain descriptions of widely distributed

120 Refers to Fuchs' Historia stirpium commentarii insignes (1542); on Galen, see Scarborough 2009, 213-232 and Everett 2012. 
plants in alphabetical order, and the second of rare plants in the same order. On the other hand, Gessner also considered, without paying attention to the fact of whether plants are widespread or rare, describing carefully in detail in one volume the nature of the plants, their names, their appearance, their temperaments and effects according to the order of their elements, but in another volume, the grammatical subjects, the etymological origin of the names ${ }^{121}$ as well as improvements in the texts, and in every respect to practise philology. Of these volumes the latter could have been designated as a lexicon of the plant names, but the former as a natural history of medical and other objects. ${ }^{122}$

But after he had decided to combine everything together, thereby conflating the material in one and the same work if he had remained alive, he pointed out to me that I, too, if he should depart this life, should obey the procedure and method which he had observed earlier in the history of animals, namely, that the first chapter, which he elsewhere wanted to be designated by the letter A, would be concerned with the name (of the plant). ${ }^{123}$

For this chapter, Gessner had collected (names from) probably more languages than anyone before him. Ancient Latin names from Pliny and Celsus, new and foreign Latin names of more recent authors. Hebrew names from his reading of the Old Testament and its dictionaries. Arabic and Persian names from those barbaric writers who had excelled in medicine, from whom he had gathered much textual corruption, such as interchanging of letters as read by some of these writers; he has laboured intensively, as I have said, and has interpreted and clarified very much from the Arab writers. Greek names from Theophrastus, Dioscorides, Galen, and lexicographers. ${ }^{124}$ Italian names from Matthiolus, Amatus (Lusitanus), (Luigi) Anguillara, ${ }^{125}$ etc. Rhaeto-Romance names, that is, the language of the Rhaetian people in the Alps, and [names communicated] from different friends. French names from (Jean) Ruel, and on the basis of his own observation, Spanish names

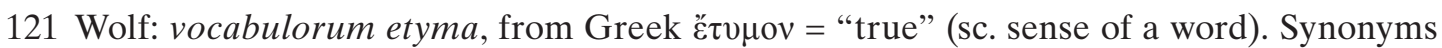
for etymon are in Gessner's works vocabuli ratio, causa nominis, vis verbi or nominis origo (Friedrich 1995, 97-98); by such an etymological approach, according to ancient tradition, "the thing itself" (res ipsa) of the referenced object can be revealed.

122 Gessner had already made a similar division into an alphabetical lexicon and a systematic encyclopaedia ("Historia") in his great bibliographical project, the Bibliotheca universalis (1545) and the Pandectes (1548), see Mayerhofer 1965.

123 For details, see my complementary essay.

124 It remains completely indeterminate which lexicographers Wolf means. On the GreekByzantine and Latin authors of antiquity and the Middle Ages, see Alpers 1990 and Miethaner-Vent 1986.

125 On Amatus and Anguillara, both devotees to Dioscorides, see Greene 1983, 998 and 723-746. 
from Matthiolus, Amatus [Lusitanus] he could find. German names partly from his approximately 20 -year-old edition, ${ }^{126}$ partly from Fuchs and Bock (Tragus), etc. Dutch names (Belgica) from (Rembert) Dodoens (Dodonaeus). English names from (William) Turner and from the dictionary of (Thomas) Elyot, Illyrian names, ${ }^{127}$ also Bohemian and Polish names from various writers. Names from different barbaric languages, older names from the name (synonym) lists added to Dioscorides, and more recent names, as well as Turkish, from a description of the New World. ${ }^{128}$ These names Gessner recorded in so many languages, but it was in no way possible to do so in all languages.

The second chapter, or "B", Gessner had devoted to descriptions of the sexes, leaves, roots, fruits, seeds, and the like, to which he intended to prepend the views of the ancient authorities Theophrastus, Dioscorides, Pliny, and others.

The third chapter, or "C", was conceived for flowering, as the plant Heliotropium, according to Theophrastus, flourishes only during solstice; or when the plants germinate and bear fruit; or at which places they grow particularly abundantly due to the quality of the habitat, as the cucumbers and gourds strive for the water in such a way that, when the water penetrates into their vascular system from nearby, they are known to creep towards (the source) within a short period to settle down there, and that, on the other hand, if (the place) dries out, curve away again.

In the fourth place, under the letter "D", Gessner wanted to explain the sympathies and antipathies which the plants sometimes have among themselves, sometimes with various other things. ${ }^{129}$ As an example, he again uses the same gourds, which, as they desire the water, but so bitterly detest oil that they, when placed near oil instead of water, turn completely over, or, if this is scarcely possible, twist away. On the other hand, although Adiantum (maidenhair fern) loves rivers and springs, it is neither wettened by water nor absorbs water because it wants to remain dry. ${ }^{130}$

126 Refers to Gessner's Historia plantarum et vires ex Dioscoride, Paulo Aegineta, Theophrasto, Plinio, \& recentioribus Graecis, iuxta elementorum ordinem (Venice 1541) and Catalogus plantarum latine, graece, germanice et gallice (Zurich 1542).

127 At Gessner's time, "Illyrian" mainly referred to languages in the western part of the Balkan Peninsula, that is, Croatian and Serbian, see Gessner 1555, 52-56.

128 One of Gessner's main sources regarding the New World was Johannes Huttich's Novus orbis regionum ac insularum veteribus incognitarum (Basel 1532) and André Thevet's Les singularitez de la France antarctique, (Paris 1557); see also Leu 1992. Wolf's association of Turkish with the New World remains obscure.

129 Explained in my complementary essay.

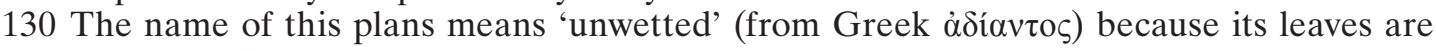
water-repellent. 
In the fifth chapter, under the letter "E", the cultivation of plants or agriculture and horticulture should be explained. For example, during the planting and grafting of certain plants, the lunar phase must be taken into account, as there are also some plants and trees which, when planted while the moon turns to the earth sign, ${ }^{131}$ develop rather vigorous underground parts. Above, however, they will spread out more branches and burst from fruits and leaves, unless the moon was hidden. ${ }^{132}$

In the sixth chapter, or letter "F", the benefits of plants should be dealt with which might be given to the body in the form of food. First of all those plants which are not useful as food; further, which plants are medically healthy or wholesome, and whether such plants should be given as a mild or strong diet. [51r] Then also a lot about the preparation, partly from ancient as well as currently common recipes, partly arrived through careful and attentive observation of Gessner himself and from other medical doctors.

The seventh chapter, with the letter "G", will contain the remedies and faculties (efficacies) of the simple medicines, derived from books of ancient and more recent authors, from many manuscripts, and from their own experiments, and from friends; it will also include the 'temperaments' (mixing ratios) and secondary, tertiary, and quaternary faculties (of the individual substances). ${ }^{133}$ In this chapter many marvellous things and mysteries of nature will be mentioned, and everything will be dealt with in a very extensive and detailed form.

In the last chapter, under the letter " $H$ ", philology would have had a place. In this chapter everything should be gathered that, as will become clear, pertains to grammar, to various languages, proverbs, parables, fables, sayings of poets - in short, subjects related more to words than to physical things. ${ }^{134}$ Even though in the investigation and explanation of all these things, the opinions of the scholars who have contributed somewhat to this part of natural history (physiologia) are extremely varied and diverse, and many great disputes have arisen by this, our Gessner had decided for this contro-

131 In astrology, the 'earth signs' are Taurus, Virgo and Capricorn.

132 The belief in the influence of the celestial bodies on the life of the plants (and animals) had in the $16^{\text {th }}$ and $17^{\text {th }}$ centuries some adherents even among otherwise very rational scholars (Debus, 1978, 12; on astrobotany, see Arber 1986: 247-263; on the ancient roots of this tradition, Ducourthial 2003). Wolf himself has published many astrological calendars ("Laasbüchlin", readers), see for example the edition of 1570. All this however hardly applies to Gessner, who was sceptical in this respect and for instance experimentally rebutted an influence of the moon on the inner life of mice (see Springer and Kinzelbach 2008, 33).

133 See the extensive notes in my complementary essay.

134 The last sentence is a nearly verbatim quotation from Gessner's Historia animalium 1, $1551, \beta 1 \mathrm{v}$ (Preface to the reader); cf. Gmelig-Nijboer 1977, 163, whose translation is a bit erroneous: similia are parables, not "analogies", and apologos are fables, not "apologies". 
versial work the following: not to interfere too harshly with any of the more recent writers, whose views he did not share, in order to not incite them to quarrelling and struggling against themselves.

He had even thought it would be better that if he should not agree with someone, to expound the truth not with words, quarrelling and slander, as the [shrewish] baker women ( $\dot{\alpha} \rho \tau 0 \pi \hat{\omega} \lambda_{1} \delta \varepsilon \varsigma$ ) of Euripides, ${ }^{135}$ are accustomed to, but with the facts themselves, and as far as possible with arguments. I like the

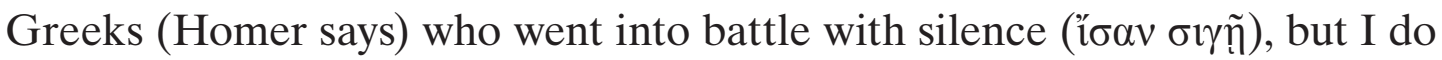
not like the Trojans who rushed forth into fight with noise and shouting $\left(\kappa \lambda \alpha \gamma \gamma \tilde{n} \tau^{\prime} \dot{\varepsilon} v_{0} \pi \tilde{\eta} \tau^{\prime}\right){ }^{136}$

And though this method in general appeared to Gessner at this time to be perfectly suited for completing this work (certainly for the reasons I have just listed) he was nevertheless well aware that, since he had less than a year's work still before him, ${ }^{137}$ different circumstances make different approaches seem advisable.

He therefore left it me to change this method, after consulting friends and experts, for reasons of time or other circumstances, and to use, according to a plan which takes into account the current situation (which is, as the poet says, ${ }^{138}$ in all things of the first importance), [51v] the best and, in particular, expert-approved method.

\section{Final request for support}

And this, in fact, is all that Gessner had told me about his history of plants before his death, and what I also wanted to tell you, great Crato, and the other experts in botany. But, chiefly, let them all firmly believe that I am not merely zealously and diligently preserving all that he himself had collected for the completion of the work, but that I, too, if I can fulfil it, and if it can be fulfilled, as in Homer Venus speaks to Juno, ${ }^{139}$ will as soon as possible pursue the publication of his work. Even if it takes a few more days, I would certainly

135 Aristophanes, Frogs 858. The plot of Aristophanes' comedy is a contest between the playwrights Euripides and Aeschylus; already quoted by Gessner, Historia animalium 4, $1558, \beta 1 \mathrm{r}$ (Preface to the reader).

136 Homer, Iliad 3.1-8.

137 Wolf: quoniam unius anni labor non erat futurus. This could also be translated as "since not even a year's work was still needed", but I think my first translation corresponds better to Gessner's state of mind in 1565. As Gessner's letters show, he felt old, sick, and close to death (cf. Simmler 1566, 18-19 and Hanhart 1824, 274-279). In contrast to Wolf, who in the "Pollicitatio" exuded great confidence, Gessner apparently had few illusions about the chances of completing the plant history.

138 Terence, Heautontimoroumenos ("The self-tormentor") 2.3, line 123: rerum omnium est primum.

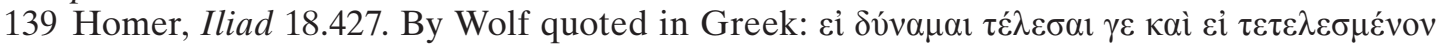
है $\sigma \tau \alpha$. 
not allow the date to be missed by much additional time. However, the greatness and mass of the future work, as well as the multiplicity and variety of the images, will cause no slight difficulty; and because it is also extremely difficult to find recognition for a work by someone else, there is no doubt that for these reasons, a rapid acceptance and distribution of the finished work is endangered.

But also my intellectual tenuity regarding the work increases the difficult situation. Because I am not particularly informed by virtue of genius or scholarship, or by practical experience, I fear that I can hardly bring to the public in a scholarly way what the great Gessner has created for us during so many vigils and exertions by day. I am aware that this work requires an artist, and the more I recognize this, the more I recall to memory the age-old poem of the Orphic poet: ${ }^{140}$

A man is sought endowed with patient mind, and full of zeal, to toil with me inclined; eager to learn, and willing to be taught.

But because I know that these treasures were given to me by the will of the Almighty God; and to Gessner himself it appeared this way, enough that he left them to me so that I without doubt might distribute them generously and faithfully to other lovers of the science, and might not - which some people, when something happens to fall into their lap by chance, tend to be superficially concerned with, but immediately see problems and difficulties withhold them from posterity through enviousness. I will finish this work, under favourable conditions, [52r] God loves to aid the man who toils, as Aeschylus says ${ }^{141}$ perhaps not the way I would wish, and not with regard to the significance of the matter, but in any case as well as I will be able to do so by means of my mental and intellectual abilities. For if my qualifications were as great as my willingness and my desire, I would hope, or rather be sure, that I will mostly prove successful.

But I prefer more that the ability of experts on this so important matter is considered than my willingness (to cope with the task), and that I more be judged as bold rather than envious. If boldness is not reprehensible in this matter and derives from honest intent, it can be called a venial sin, but it is no offence. Disgrace is a very bad vice, and all people unanimously dislike

140 The lines are from the pseudo-Orphic poem Lithica, dated from the fourth century AD. I have slightly modified the translation by King 1865,377 . Wolf quotes the original Greek:

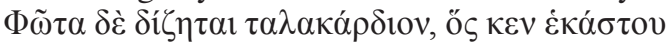

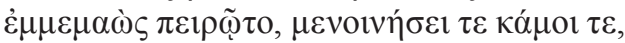



141 Quoted by Wolf in Greek: 
an envious person, while many apologize to someone with an honest behaviour, and no one will accuse him.

I thus shall try to accomplish that most beautiful part of the greening and sprouting nature which has been created by our highly celebrated Gessner, which he left to me a fairly long time after he had put it together with great effort and nighttime work. But in such a way that I add nothing or at most a preface to the notes, and by merely being content with Gessner's view, in whichever state I have found it written down. And I will not cease to harness all my intellectual powers, until I have reached my goal and, as it were, the destination, with the blessing of God, the Lord of all nature. If something is missed, it will by no means surprise those who are aware of the difficulties associated with these things: In great things, it is enough even to have willed. ${ }^{142}$ And in all high enterprises it is the effort that merits praise, success is after all a matter of chance. ${ }^{143}$

I, most revered Crato, must implore you and the other highly erudite friends and intimates of our Gessner, that you, as the latter has given me hope in regard to you, and as I myself had expected of you, might confirm this request according to your kindness. So it will happen, I have no doubt, that Gessner is recognised as the author of this posthumous work, and that it is approved and praised by all scholars and specialists in botany. I urge and desire you insistently to act in this way, and to advise me (as nothing escapes your ingenuity) and take up the work with me. And this I ask you now more earnestly, as if it were a matter of my own, inasmuch as it is more honourable to strive for the benefit of friends than for one's own. And indeed, [52v] this is what I wanted to promise to do when faced with such a laborious and immeasurable work on plants: I will persistently ask the best and greatest God that I, as soon as I could be of service to [at least] one of those who study the history of plants, may be honestly and immediately released from my obligation, and that others with their petitions implore the same of God, this I ask again and again.

But I also would like to ask you imploringly, most humane Crato, that you, in the first place, might judge favourably and appropriately my enterprise regarding my teacher Conrad Gessner and the history of plants most closely connected to him, which I have certainly begun with best intention and defi-

142 Greek translation by Angelus Politianus (1454-1494) of a famous sentence by the Roman poet Propertius (Elegiae 2.10.6: in magnis et voluisse sat est), incorporated in Erasmus's

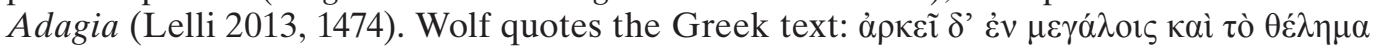
uóvov.

143 The last sentence is an unattributed quotation from Florida (4.20), an anthology of aphorisms by Lucius Apuleius Madaurensis (second century A.D.); translation from Butler 1909, 209. 
nitely as mentioned - an enterprise that I have (possibly too self-assuredly) dedicated to you.

Moreover, though I have no doubt that you, as previously towards all men, will now also act towards me with the same humanity and kindness, thanks to your firmness of character, I nonetheless beg you to grant me the same kindness which you have shown to many and to take me into the circle of your friends, if you trust my friendship only a little. In return, I offer and promise to you all my efforts and all my services at the highest level, also in case I could be in a good manner fit or useful with respect to anything else.

Farewell. Zurich, Switzerland, March 14, in the Year of Salvation 1566. 


\section{Appendix: selection of Gessner's plant woodcuts}

[53r]



Woodcut 1: Terebinth or turpentine tree (Pistacia terebinthus).

Heading: Terebinthus cum floribus et folliculo, in quo culices latent - "Terebinth with fruits including a follicle in which midges hide".

Woodcut reused by Camerarius 1586, 51. See also the variants in Figure 1 and 2 below.

\section{$[53 v]$}
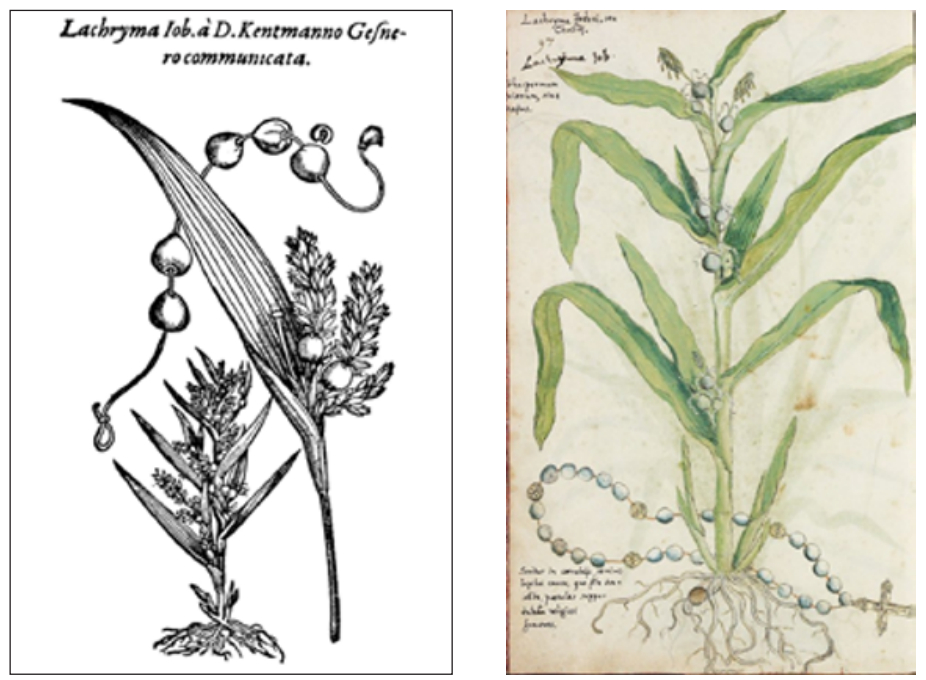

Woodcut 2: Job's-tears (Coix lacryma-jobi (L.) Lam.).

Heading: Lachryma Iob. a D. Kentmano Gesnero communicata - "Job's-tears sent from Mr Kentmann to Gessner".

On the right, the original from the Codex Kentmanus (Ms 55, fol. 97) of Gessner's friend Johannes Kentmann now housed in Tartu University, Estonia.

Missing in Gessner's botanical legacy from Erlangen University. 

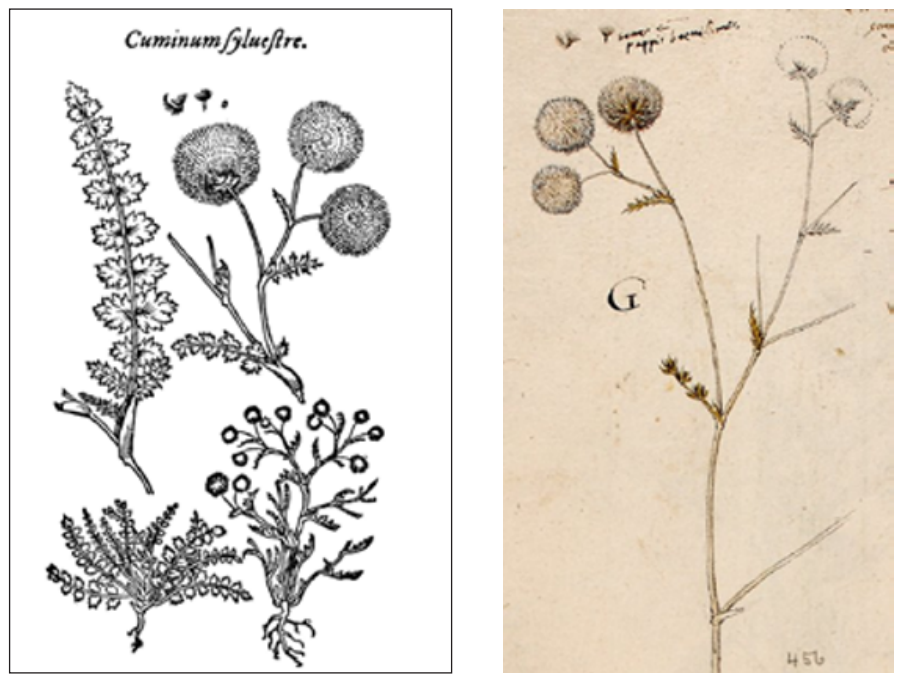

Woodcut 3: Common wild cumin (Lagoecia cuminoides).

Heading: Cuminum sylvestre - "Wild cumin".

To the right, the original from Gessner's botanical legacy at Erlangen University, see Zoller and Steinmann 1991, no. 454v. Woodcut reused by Camerarius 1586, 519.

$[54 v]$

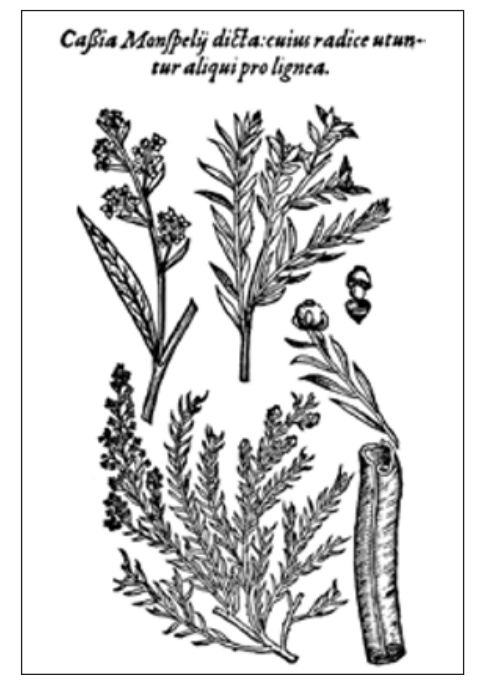

Woodcut 4: Chinese cinnamon (Cinnamomum cassia (L.) J. Presl).

Heading: Cassia Monspelii dicta: cuius radice utuntur aliqui pro lignea - "Called Cassia from Montpellier, the root of which some people use for woodworking". Woodcut reused by Camerarius 1586, 26. Provenance unknown. 
[55r]

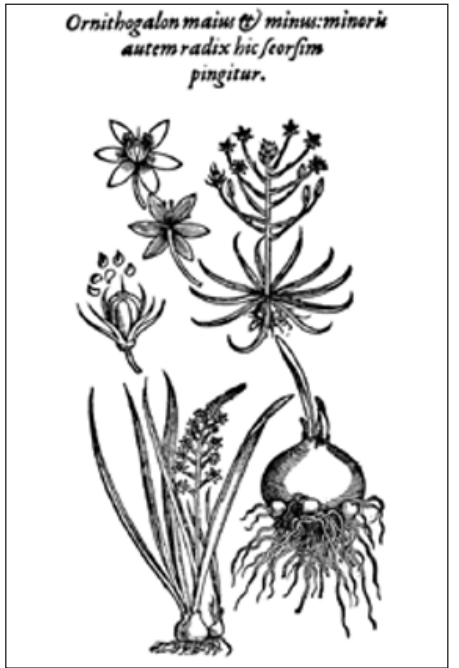

Woodcut 5: Ornithogalum spp. (Ornithogalum L.).

Heading: Ornithogalon maius et minus: minus is autem radix hic seorsim pingitur "Greater and smaller Ornithogalum, but here the root of the smaller one is separately depicted".

Woodcut reused by Camerarius 1586, 315. Provenance unknown.

$[55 v]$

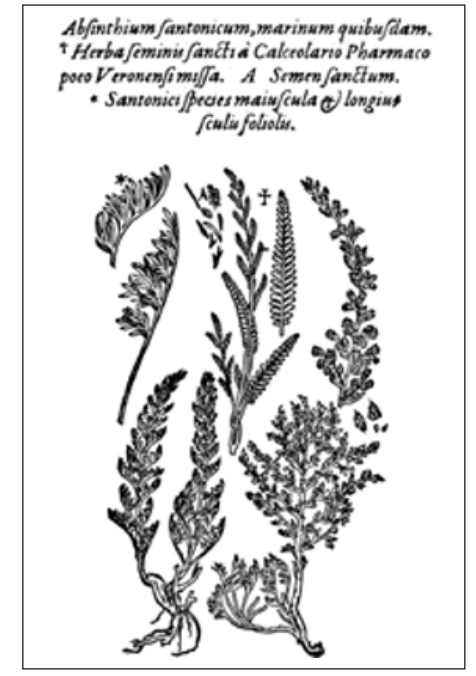

Woodcut 6: Wormwood (mugwort) spp. (Artemisia L.).

Heading: Absinthium santonicum, marinum quibusdam, $\dagger$ Herba seminis sancti a Calceolario Pharmacopeo Veronensi missa. A Semen sanctum. * Santonici species maiuscula et longiusculis foliolis. - "Absinthium santonicum, by some called marinum, $\dagger$ Semen sanctum herb, sent by the apothecary Calceolarius from Verona. "A" Semen sanctum. * The Santonicum species is somewhat larger with rather long leaflets."

Woodcut reused by Camerarius 1586, 457. Provenance unknown. 




Woodcut 7: Sow-bread (Cyclamen purpurascens Mill.).


Cyclaminus, sent from Mr Kentmann".

Included in the Codex Kentmanus (Ms 55) now housed in Tartu University, Estonia, see Rand 2014, 34. Woodcut reused by Camerarius 1586, 358.

\section{Figures}
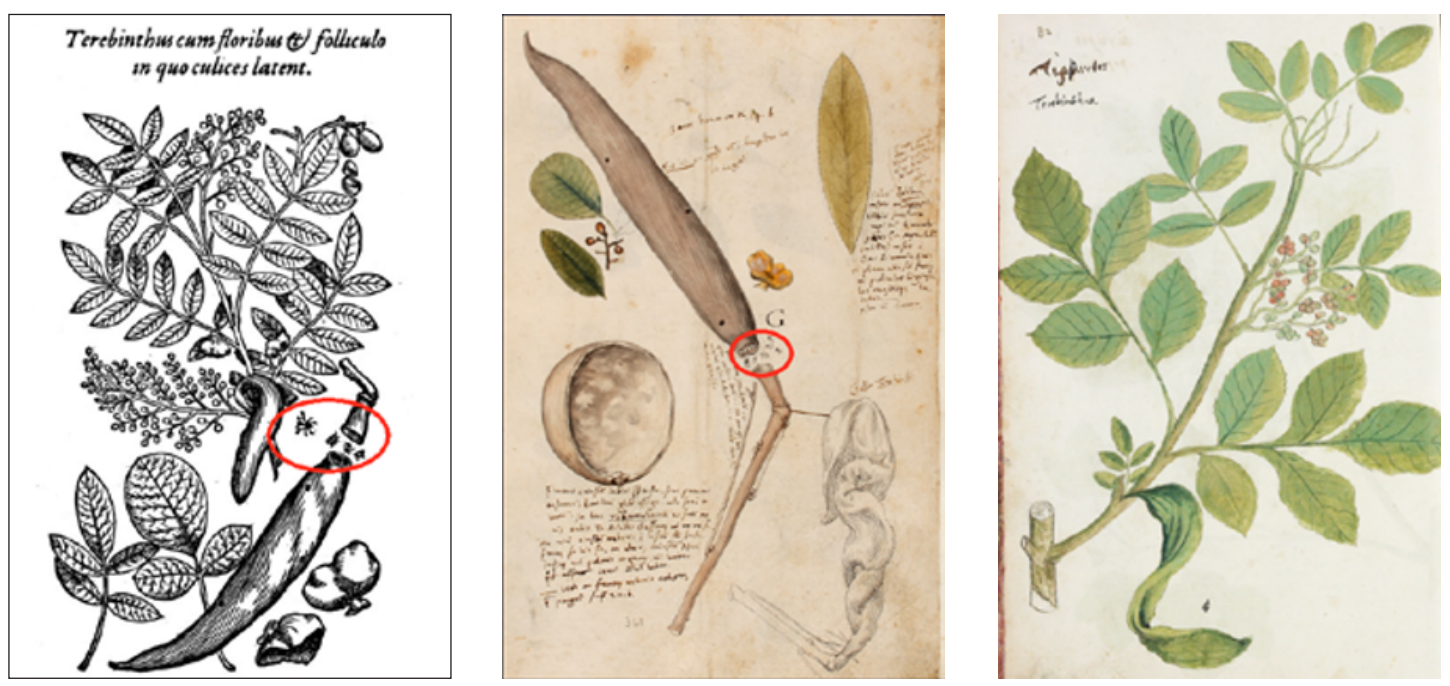

Figure 1: From left to right, (1) Wolf's "Terebinthus" (Pistacia terebinthus) with fruits including a follicle with midges (circled, in reality Aphis pistaciae, a (winged) aphid species); (2) the original drawing from Gessner's botanical legacy (see Zoller and Steinmann 1991, no. 404r), and (3) a Terebinth drawing in the so-called Codex Kentmanus (1549, fol. 82) of Gessner's friend Johannes Kentmann. 



Figure 2: Left: Two Terebinthus plants from the Libri Picturati codex (1560s), right: Terebinthus from Clusius, Rariorum aliquot stirpium per Hispanias observatarum historia $(1576,88)$.
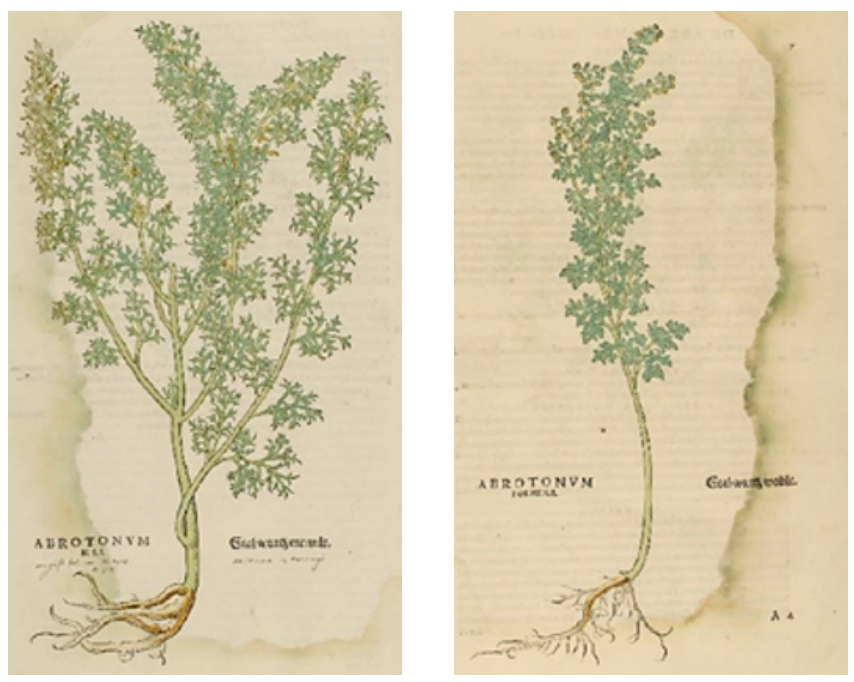

Figure 3: Specimens of a "male" (left) and a "female" (right) "Abrotonum" plant in Fuchs' herbals (1542, 6-9) and (1543, 4-7, "Stabwurtz/Staubwurtz"), respectively. The male species, based on unillustrated Greek and Latin descriptions from antiquity, has been identified (Ducourthial 2003, 522) as Artemisia abrotanum (southernwood) or Artemisia arborescens (tree wormwood), the female one as Santolina chamaecyparissus (cotton lavender), in the case of Fuchs, however, both images obviously refer to Artemisia abrotanum. The botanical notes by Meyer et al. 1999, 298 to Fuchs' images and description say nothing about the difference between the supposed two "genera". 